\title{
Total System Performance Ratio-A Systems Based Approach for Evaluating HVAC System Efficiency ${ }^{\dagger}$
}

\author{
Supriya Goel *, Michael Rosenberg, Juan Gonzalez and Jérémy Lerond
}

Pacific Northwest National Laboratory, Richland, WA 99354, USA; michael.rosenberg@pnnl.gov (M.R.); juan.gonzalez@pnnl.gov (J.G.); Jeremy.lerond@pnnl.gov (J.L.)

* Correspondence: supriya.goel@pnnl.gov

† This paper is an extended version of our paper published in ACEEE 2018 Summer Study on Energy Efficiency in Buildings, Pacific Grove, CA, USA, 12-17 August 2018. Washington DC: American Council for an Energy Efficient Economy. PNNL-SA-133468.

check for

updates

Citation: Goel, S.; Rosenberg, M.; Gonzalez, J.; Lerond, J. Total System Performance Ratio-A Systems Based Approach for Evaluating HVAC System Efficiency. Energies 2021, 14, 5108. https://doi.org/10.3390/ en14165108

Academic Editors: Paul Mathew, Jae-Weon Jeong and George S. Stavrakakis

Received: 4 May 2021

Accepted: 4 August 2021

Published: 19 August 2021

Publisher's Note: MDPI stays neutral with regard to jurisdictional claims in published maps and institutional affiliations.

Copyright: (C) 2021 by the authors. Licensee MDPI, Basel, Switzerland. This article is an open access article distributed under the terms and conditions of the Creative Commons Attribution (CC BY) license (https:/ / creativecommons.org/licenses/by/ $4.0 /)$.

\begin{abstract}
The prescriptive path is the most widely used approach for commercial code compliance in the United States. Though easy to implement, prescriptive approaches do not typically discriminate between minimally compliant, high-performing and poorly performing HVAC system configurations. Hence, to meet aggressive energy and carbon reduction goals, it is clear that energy codes will need to transition from prescriptive to performance-based approaches, a transition that is riddled with several challenges. This paper discusses a new HVAC system-based performance approach (HVAC System Performance) which provides a simpler solution to HVAV system evaluation compared to whole building performance, while keeping tradeoffs limited to specific building systems. The Total System Performance Ratio (TSPR) is a metric for evaluation of overall system efficiency instead of individual component efficiency, a solution which could also eventually facilitate the transition to a $100 \%$ performance-based code structure. TSPR is a ratio that compares the annual heating and cooling load of a building to the annual energy consumed by the building's HVAC system. A calculation software tool has been developed for determining a building's TSPR. Already incorporated into the 2018 Washington State Energy Code, this approach is also being evaluated by ASHRAE Standard 90.1 Project Committee and has the potential to provide a comprehensive performance-based approach for HVAC system evaluation and analysis.
\end{abstract}

Keywords: HVAC system performance; performance-based codes; net zero codes

\section{Introduction}

Beginning with ASHRAE Standard 90-1975, most non-residential energy codes and standards include both prescriptive and whole-building performance-based compliance paths [1]. Prescriptive paths establish minimum requirements for energy-related characteristics of individual building components such as minimum required R-values of insulation, solar heat gain coefficients of fenestration, occupancy sensors for lighting control, maximum fan power limits, restrictions on window area, etc. Most performance paths on the other hand, allow buildings to trade-off some prescriptive requirements for improved performance in other building components and systems. The improved building performance is demonstrated through whole building energy simulation. Although there are nuances to the performance paths in various U.S. energy codes and standards, they mostly follow that basic approach.

The most significant advantage of the prescriptive path is the fact that it is easy to use and understand. However, it does limit design flexibility, as it prescribes building characteristics and their performance levels, and it does not recognize the interactive effects of systems. Hence, integrated design solutions are not credited by this path. The prescriptive path in codes and standards is typically required to be cost effective, hence the rate of improvement of each subsequent code is constrained by technological feasibility as 
well as economic considerations. In some cases, improvements in prescriptive requirements come at the expense of limitations in design flexibility [2]. Highly glazed facades (over $40 \%$ of wall area in Standard 90.1 and 30\% in the International Energy Conservation Code) are not permitted prescriptively [3,4]. Washington State's energy code [5] requires that school, office, retail, and other building types be served by HVAC systems with a fan that cycles on and off to meet space heating and cooling loads and a separate dedicated outdoor air system with heat recovery to condition outdoor air. As these types of design requirements become more common, the code developers have increasingly focused on performance paths to help maintain flexibility in the design process, a capability desired by the architectural and engineering community.

\section{The Case for Performance}

Due to the limitations discussed above, it is unlikely that energy codes largely dependent on prescriptive compliance will achieve the aggressive savings policy goals espoused by many. Examples of some of those policy goals include the American Institute of Architects 2030 Challenge and ASHRAE's Vision 2020, both of which strive for new buildings to have zero carbon emissions by the year 2030 [6,7]. Figure 1 shows the rate of improvement in the prescriptive path of ASHRAE Standard 90.1 since the first edition in 1975. It shows the rate of future improvement in three ways: (i) if the Standard continues to improve at the average rate it has since 1975, (ii) if it improves at the accelerated rate it has since 2004 (not likely, as described above), (ii) and it shows the rate at which it needs to improve if it is to reach net zero energy considering a reasonable amount of rooftop solar photovoltaics [8]. As indicated by this graph, the prescriptive improvements alone are not aggressive enough to pave the path to net zero energy for buildings. The solution championed by the authors relies on a move to performance-based codes that treat the building as a system and encourage creative solutions more likely to lead to deep savings than the prescriptive alternative [9].

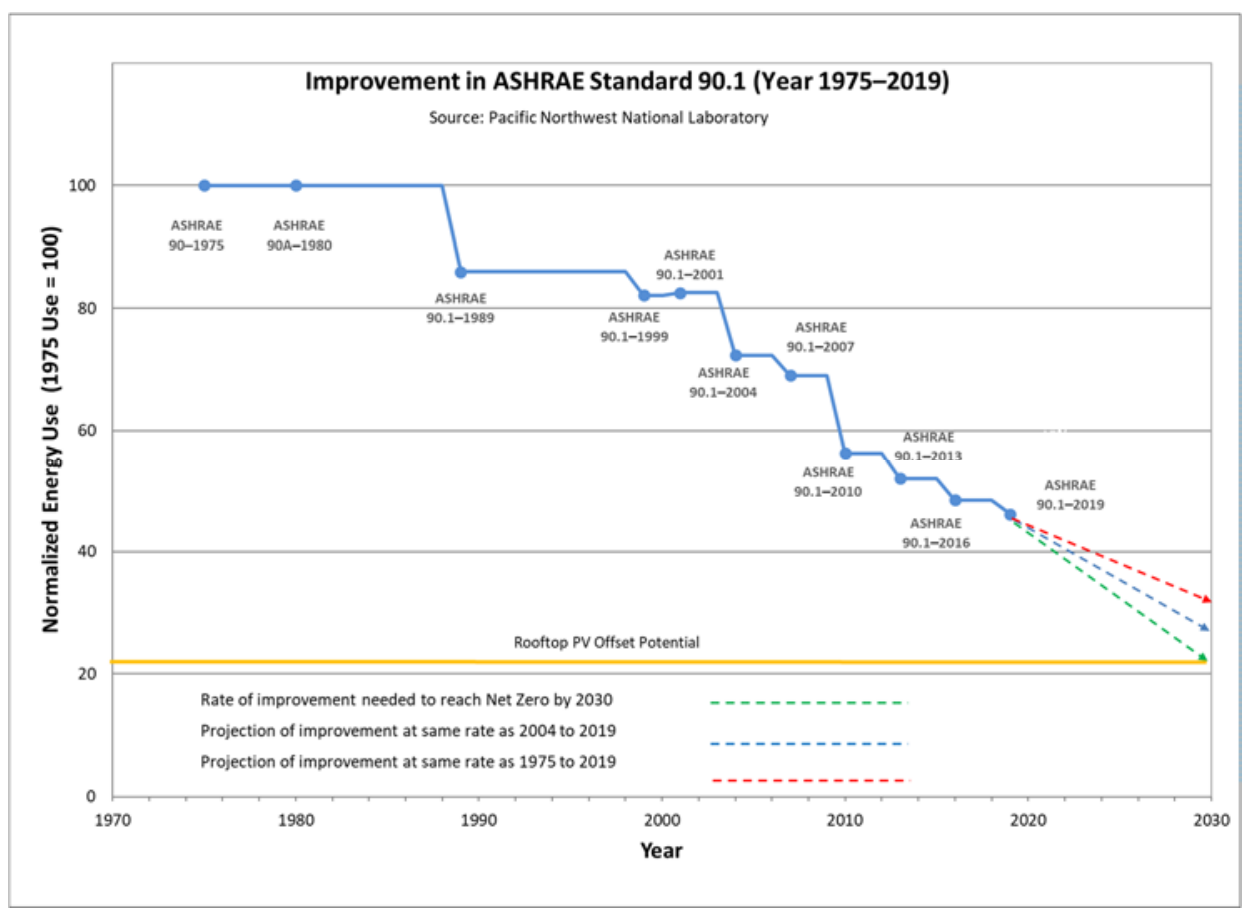

Figure 1. Improvement of Standard 90.1 over time [8]. 


\section{Total System Performance Ratio}

\subsection{Overview of Whole Building and System Performance Metrics}

Building energy performance has typically been evaluated at a whole-building level (energy use intensity, peak demand) or at equipment level (e.g., chiller efficiency coefficient of performance (COP)) [10]. Whole building metrics like energy use intensity (EUI), peak demand, and thermal energy demand intensity (TEDI) represent whole building performance normalized by floor area, where EUI is the whole building energy use normalized by floor area and TEDI is the space heating and ventilation output normalized by floor area [11]. A whole building metric can be affected by the performance of any building system, including building envelope, lighting, HVAC, SHW, etc. and isolating the performance of individual building systems (for instance, reduced infiltration rate) using whole building metrics can be challenging. For the purpose of this study, a system refers to an aggregation of individual equipment and components that serves a specific function in the building, for instance, a heating system, a lighting system, a refrigeration system, etc. A system would comprise of multiple pieces of equipment, for instance a HVAC system could include heating coils, cooling coils, reheat coils, fan, ducts, heat recovery system, and equipment controls such as resets, variable frequency drives, etc. Metrics for presenting building performance at a system level (e.g., lighting system, HVAC system, etc.) are more appropriate for evaluating the performance of building systems, however, unlike whole building metrics, these are not well defined [10]. Li et al. (2020) documented the importance of system level key performance indicators (KPI) and noted the limited use and availability of HVAC system performance metrics through their study.

National model codes in the US evaluate HVAC systems at either an equipment level (prescriptive approach) or through a whole building performance approach (the Performance Rating Method or Energy Cost Budget) [12]. Prescriptive evaluation of HVAC systems includes the equipment's rated efficiency to determine compliance with the code. Commonly used HVAC system efficiency metrics include Coefficient of Performance (COP), Energy Efficiency Ratio (EER), Seasonal Energy Efficiency Ratio (SEER), Integrated Part Load Value (IPLV), Heating Seasonal Performance Factor (HSPF) and Annual Fuel Utilization Efficiency (AFUE). These are the fundamental ratings used to quantify the efficiency of heating and cooling equipment and are highly dependent on operating conditions like dry bulb or wet bulb temperature. Though excellent metrics for evaluating efficiency of system components at standard conditions, these ratings are not effective in quantifying actual system performance which is affected by part load conditions and the total system configuration. There are also prescriptive requirements for associated HVAC system components such as energy recovery ventilation (ERV), economizers, and variable frequency drives on fans and pumps, as well as control requirements for things like temperature resets, fan speed control, and reheat limitations. However, each of these requirements is evaluated in isolation. While a whole building performance-based approach looks at the overall building performance, it is resource intensive, and distilling HVAC system performance from that analysis can be quite challenging.

An alternative code compliance method for HVAC systems, an "HVAC power density" (similar to a lighting power allowance) was explored by Kavanaugh [13]. HVAC power density (HvacPD) is expressed in terms of power input per unit area for the entire HVAC system. Input power density thresholds for HVAC equipment in Btu/hr- $\mathrm{ft}^{2}\left(\mathrm{~W} / \mathrm{m}^{2}\right)$ are established by building type and climate zone. The primary drawback with such a concept is that HVAC system capacities must be sized to accommodate winter and summer extremes, whereas actual HVAC systems typically operate under part load conditions for most hours of the year. As a result, the annual energy impact that is based primarily on efficiency at part load conditions is undervalued by the HVAC power density approach, which is based on peak energy use at design conditions that occurs only a few hours a year. For example, the addition of an airside economizer will significantly improve the annual performance of an HVAC cooling system, but will not reduce the power density. Another issue is that HVAC system power density is influenced by the building heating and cooling 
loads as well as the performance of the HVAC system itself. Hence a building which is heavily insulated and has a tightly sealed building envelope with good solar protection of the fenestration will have significantly lower heating and cooling loads compared to a building with a poorly designed or poorly constructed building envelope. A building with lower internal loads, such as fewer computers and other heat-generating equipment will also have a lower cooling load. An optimal metric for evaluating HVAC system performance should therefore be independent of the building loads [14]. An optimal metric would be one that considers all components of the HVAC system including system controls, account for part load performance and at the same time, normalize for building loads. The TSPR metric accounts for all these requirements as it measures the amount of energy required to deliver each unit of heating and cooling to the building over the course of a typical year [14,15]. Hence, systems using less overall energy to meet the building's annual heating, cooling and ventilation loads would be rated as more efficient.

There have been similar studies [16-18] which defined HVAC system level metrics. Lombard et al. (2011) defines several energy efficiency indicators, where energy efficiency (घ) is defined as the ratio of useful energy output to energy input and Energy Intensity (EI), is defined as the ratio of energy input to service output, i.e., the amount of energy needed to provide the unit of service. It identifies four different levels (global, services, subsystems, equipment) for which HVAC system efficiency can be quantified and defines metrics for the same. TSPR metric expands upon the global efficiency indicator (ロHVAC), defined as the ratio of HVAC ideal demand to the HVAC energy use. As identified by this paper, the biggest challenge of a global HVAC system metric is its dependence on simulation software to quantify the numerator (ideal demand) and is often unintelligible to consumers as it is difficult to translate to energy consumption. The System Performance approach addresses both of these challenges by providing a simplified simulation methodology, which has been implemented into a web-based tool and also defines reference HVAC system configurations that provide a basis for comparing the candidate building's performance.

Slightly less related, but still worth mentioning, is an earlier effort to evaluate HVAC system performance: the multizone efficiency index (MEI). The MEI [19] is calculated for heating and cooling systems separately and is a ratio of the annual heating or cooling energy consumed by an ideal single zone system to the measured annual heating or cooling energy consumption. Specific to multi-zone systems, the highest value of an MEI is 1. A lower value is indicative of high simultaneous heating and cooling energy consumption. The TSPR metric is applicable to all systems and is also useful for comparing the performance of single zone systems against multi-zone systems.

Wang, 2015 and Liao et al., 2018 proposed a system level metric, Load Energy Ratio (LER) which builds upon the System Performance Ratio approach [15] and uses measured energy data from buildings to evaluate HVAC system performance. LER is a ratio of the total building load ( $\left.\mathrm{Q}_{\mathrm{BSL}}\right)$, which includes envelope loads, internal gains, and ventilation loads, to the total energy input $\left(\mathrm{E}_{\mathrm{BS}}\right)$. $\mathrm{E}_{\mathrm{BS}}$ is represented as the total HVAC energy input costs for all HVAC system components including air-side and water-side components. These papers lay out a methodology for calculating the LER for heating systems and cooling systems using measured data and tests the same for a campus building in Texas.

The biggest difference between the TSPR methodology and the LER metric is the fact that TSPR is a simulation-based methodology using an annual metric to represent system performance. A metric by itself does not provide enough useful information which can be used for decision making. For instance, a building EUI of $40.1 \mathrm{kBtu} / \mathrm{ft}^{2}$ is not useful for decision making until there is additional information provided such as EUI of similar buildings in similar climate zones which can help benchmark the performance of the candidate building. Similarly, a TSPR of 12.1 or a LER of 0.81 is not very informative until it is supplemented with additional information which can benchmark the system's performance against a baseline or a reference. Hence, in addition to the TSPR metric, the System Performance approach proposed in this paper defines a simulation-based methodology for evaluating the candidate building's performance against a reference case. 
The reference or the baseline case can be defined based on the desired outcome of the energy code or energy efficiency program (example- cost savings, electrification, reduction in carbon emissions etc.). This methodology provides a framework which can be adopted by jurisdictions and energy efficiency program managers to meet the policy objectives being targeted.

Utility incentive programs could apply this approach to analyze HVAC system retrofits, identifying controls and components that improve overall HVAC system performance. Similarly, energy codes could define a minimum TSPR requirement, such that it would be difficult for less efficient systems to meet code. A performance-based solution approach would also need to be significantly simpler than the standard whole building performance approach, to provide a solution more informative than a prescriptivebased approach but without some of the challenges associated with a whole-building performance-based approach. This is the basis of TSPR that has been adopted by the 2018 Washington State Energy Code as a compliance requirement for eligible buildings and systems [5].

\subsection{Definition and Calculation}

As described above, the TSPR is a ratio of the annual heating and cooling provided for a building, to the energy consumed for heating, cooling, and ventilating a building. The calculation is performed using whole building simulation, similar to whole building performance energy modeling, but in a simplified manner as discussed in this paper [14].

TSPR is calculated as the ratio of the sum of a building's annual heating and cooling load to some metric that represents the annual energy consumed by the building HVAC systems. That metric could be annual site energy, source energy, energy cost or carbon emissions. The appropriate TSPR metric can be chosen based on the policy goals and priorities of the jurisdiction adopting the HVAC System Performance approach. The simplest representation of energy consumed by the HVAC system would use site energy (energy consumed at the site); however, that approach fails to consider the upstream impacts of generation and distribution losses and does not correspond well with greenhouse gas and other emissions [14]. Source energy use or energy cost would include the impact of generation and distribution losses and carbon emissions would directly address greenhouse gas emissions. The section below uses energy cost to explain the TSPR concept which is the preferred metric for ASHRAE Standard 90.1.

A larger TSPR indicates lower HVAC energy use to meet the loads, and therefore can be considered a more efficient system. The annual heating and cooling loads include envelope loads, internal loads due to lights, equipment, and occupants, as well as ventilation and infiltration loads. This metric provides a single evaluation criterion which addresses all components of the HVAC system including all distribution systems. It considers both full and part load performance, includes distribution system effectiveness, and accounts for system controls. This differs from standard system efficiency ratings (such as SEER, COP, or kilowatt hours per ton) that usually address part of a system and fail to account for all the system inefficiencies that may be present within a building as well as their interaction with building loads and ventilation requirements. In addition, such component efficiency ratings are based on standard rating conditions that may not reflect actual building conditions and the ambient conditions at the building site. The HVAC System Performance approach accounts for all these parameters to provide a comprehensive evaluation of a building's HVAC system [14].

To calculate the TSPR, annual energy costs of all system components, including auxiliary components, are included in calculations for a complete HVAC system evaluation. Hence, the total HVAC energy cost includes fuel-fired and electric heating coils (including reheat coils), direct expansion cooling coils, boilers, chillers, heat rejection, energy recovery, and distribution system fans and pumps [14]. The electricity and fossil fuel rates can be determined by rules established by the adoption jurisdiction, typically based on actual project cost or using regional costs such as those published by the U.S. Energy Information 
Administration's Annual Energy Outlook (EIA AEO). An example using electricity and natural gas with costs from the 2020 EIA AEO is shown in Equations (1) and (2) [20]. $E_{\text {Heating-elec }}$ and $E_{\text {Heating-gas }}$ account for the energy use of all heating coils in a system, include pre-heating coil, main heating coil, supplementary heating coil and reheat coil. Similarly, $E_{\text {fan }}$ includes the energy use of all fans in a system, including the supply fan, exhaust fan, return fan and relief fan. EPump includes the energy use of all hot-water pumps, chilled water pumps and condenser water pumps, serving the system. The impact of HVAC system controls, such as fan static pressure and variable speed control is accounted for through the energy use of that particular component. For example, the energy consumption of a fan in a variable air volume (VAV) system with static pressure reset will typically be lower than that for the same system without static pressure reset. Hence, the component $\mathrm{E}_{\mathrm{fan}}$ accounts for the impact of system controls affecting fan energy use, similarly $\mathrm{E}_{\text {cooling }}$ accounts for the impacts of economizer control and $E_{\text {Heating }}$ accounts for the impact of energy recovery.

Electricity Cost $_{\text {Total }}=\left(\mathrm{E}_{\text {Heating-Elec }}+\mathrm{E}_{\text {Cooling }}+\mathrm{E}_{\mathrm{Fan}}+\mathrm{E}_{\text {Pump }}+\mathrm{E}_{\text {Heat-Rejection }}+\mathrm{E}_{\text {Heat-Recovery }}\right)[\mathrm{kWh}] \times \frac{\$ 0.1052}{\mathrm{kWh}}$

$$
\text { Gas Cost } \text { Total }=\left(\mathrm{E}_{\text {Heating-Gas }}\right)[\text { Therm }] \times \$ 0.752 / \text { Therm }
$$

where:

- $\quad \mathrm{E}_{\text {Heating-Elec }}=$ heating electric energy consumption $(\mathrm{kWh})$

- $\quad \mathrm{E}_{\text {Cooling }}=$ cooling electric energy consumption $(\mathrm{kWh})$

- $\quad \mathrm{E}_{\mathrm{Fan}}=$ fan electric energy consumption $(\mathrm{kWh})$

- $\quad \mathrm{E}_{\mathrm{Pump}}=$ pump electric energy consumption $(\mathrm{kWh})$

- $\quad \mathrm{E}_{\text {Heat-Rejection }}=$ heat rejection energy consumption $(\mathrm{kWh})$

- $\quad \mathrm{E}_{\text {Heat-Recovery }}=$ heat recovery energy consumption $(\mathrm{kWh})$

- $\quad E_{\text {Heating-gas }}=$ heating gas energy consumption (therm)

To determine the annual heating, cooling, and total loads for each building, the simulation uses a special HVAC system type available in US DOE's EnergyPlus software called the Ideal Loads system [21]. This system calculates the annual heating and cooling load (including ventilation load) for each zone in the building and supplies heating or cooling air to meet the set-points at a system efficiency of $100 \%$ based on the specifications of the system. This system includes setpoints for temperature and humidity control, and outdoor air quantity, so it truly represents the complete load on the HVAC system. Thus, the TSPR is calculated according to Equation (3) [14].

Total System Performance Ratio $=\frac{\text { Ideal annua heating load }+ \text { Ideal annual cooling load }(\mathrm{kBtu})}{(\text { TotalElectricityCost }+ \text { TotalGas Cost })(\$)}$

A cooling system performance ratio (C-SPR) and heating system performance ratio (H-SPR) can also be separately calculated to provide a discrete evaluation of the heating and cooling, using the methodology defined in the section above. For this purpose, component energy use would be split between heating and cooling based on the mode of operation of the system while that component is running. Straightforward for single zone systems, this gets challenging for multi-zone systems with reheat which can have simultaneous heating and cooling. Goel et al., 2014 defines a methodology for splitting fan energy use based on the model of operation of the system and lays out the process for calculating and heating and cooling system performance ratio.

\section{HVAC System Performance Approach in the Washington State Energy Code}

The Washington State Energy Code adopted the TSPR metric as a performance-based requirement for HVAC systems serving office, retail, education, and library occupancies [5]. The methodology as defined by WSEC requires the TSPR of the proposed building design to be compared against the TSPR of the same building, but with a standard reference 
(baseline) HVAC design, to determine compliance. This approach normalizes for envelope and internal loads and schedule of operation by keeping them the same between the proposed and the baseline building. Hence the heating and cooling loads are effectively the same between the baseline and proposed, and a comparison of the TSPR for proposed and baseline provides a holistic evaluation of the HVAC system's efficiency in serving those loads. The following sections describe this methodology, the compliance requirements as established by the WSEC and the development of the HVAC System Performance tool.

Washington State Energy Code stakeholders, following policy recommendations by the Washington State Department of Commerce have embraced the use of carbon emissions as the metric for this approach, instead of an energy cost metric [14]. The emission factors used in the WSEC are shown in Table 1a,b [5].

Table 1. Carbon emission factors used for TSPR calculations in the Washington State Energy Code. (a) IP units; (b) SI units.

\begin{tabular}{ccc}
\hline & (a) & \\
\hline Type & $\mathbf{C O}_{\mathbf{2}} \mathbf{e}(\mathbf{l b} /$ Unit) & Unit \\
\hline Electricity & 0.70 & $\mathrm{kWh}$ \\
\hline Natural Gas & 11.70 & Therm \\
\hline Oil & 19.2 & Gallon \\
\hline Propane & 10.5 & Gallon \\
\hline Type & $\mathbf{( b )}$ & \\
\hline Electricity & $\mathbf{C O}_{\mathbf{2}} \mathbf{e}(\mathbf{k g} /$ Unit) & Unit \\
\hline Natural Gas & 0.09 & MJ \\
\hline Oil & 0.05 & $\mathrm{~m}^{3}$ \\
\hline Propane & 2301 & $\mathrm{~m}^{3}$ \\
\hline
\end{tabular}

\subsection{Modeling the Proposed Building Design}

To comply with the 2018 Washington State Energy Code, the TSPR of a proposed building design is required to be greater than the TSPR for a standard reference building (baseline) design. The baseline design TSPR is determined using the same building model as the proposed building design, but by replacing the HVAC system with one that is specified in the code [14]. The baseline HVAC design represents standard energy-efficient design practice as agreed to by code development stakeholders. All aspects of the baseline design comply with the code and some aspects exceed the code's minimum prescriptive requirements. This approach places a great deal of importance on the selection of the appropriate HVAC system type [14].

The 2018 WSEC also defines rules for modeling the proposed building. These include a simplified modeling approach for the building geometry, prescribed envelope assembly types, prescribed interior loads, HVAC system specifications, etc. The building geometry is required to be defined using multiple 'Blocks'. Blocks, as defined by the Washington State Energy Code, are a "geometric concept used in energy simulation representing a whole building or a portion of a building with the same use type and served by the same HVAC system type" [5]. If the area of the building represented by each block includes multiple pieces of similar equipment type, the energy code specifies an approach to combine them. The approach includes calculation of design heating and cooling capacity, weighted average efficiency, design airflow and fan power which is used in the simulation analysis. The building envelope is defined using predefined construction assembly types, as specified in the WSEC, for exterior roof, above grade and below grade walls, exterior and slab-ongrade floors. A user is required to specify the assembly U-factors, F-factors and C-factors consistent with the proposed design. A user is also required to specify fenestration area for 
both skylights and windows through a skylight to roof area ratio and window to wall area ratio input and thermal properties through U-factor and solar heat gain coefficient. The modeling rules in the code specify standard operation schedules, plug loads and ventilation rates, as defined by Appendix C in ASHRAE 90.1-2019 [3]. Lighting power density is fixed to the prescriptive requirements by building type, as specified by the 2018 WSEC. The simplifications in the form of weighted average calculations allows a user to simplify the building geometry and thermal zone layout. The requirement to specify all HVAC systems, as designed, provides a format for reviewers to verify the information entered in the tool against design drawings.

The intent of these simplifications is to reduce the level of effort, time and cost associated with developing an energy model. The input parameters for defining the proposed building design are limited to a standard set of inputs which would be applicable to all buildings pursuing compliance through the HVAC System Performance path [14]. Appendix C in ASHRAE Standard 90.1 is used for default values related to basic modeling assumptions, such as schedules of operation, plug loads, ventilation loads, equipment performance and operation, etc., providing reliable and consistent default values for the baseline and proposed designs [3]. The code requires the baseline building model to be automatically generated by the tool implementing the HVAC System Performance approach and should be specified to be the same as the proposed design except the HVAC systems, which are modified as prescribed by the WSEC. Any simulation tool used to demonstrate compliance with the HVAC System Performance approach would be required to implement these simplifications for the proposed building design and automatically generate the baseline building design.

\subsection{Establishing a Baseline Building Design HVAC System}

Unlike most other energy codes, the WSEC has placed system type requirements on certain occupancies since 2015 [22]. Offices, education facilities, schools, libraries, and fire stations are required to use cycling space conditioning systems combined with a Dedicated Outdoor Air System that includes energy recovery [14]. They are not permitted to use standard VAV reheat systems or other system types that combine space conditioning with delivery and treatment of outdoor air. Due to this, the first implementation of HVAC System Performance in the WSEC is being applied to office, education, library, and retail occupancies. Together, these three building types represent approximately $30 \%$ of new construction starts in Washington State for non-residential buildings [23]. The City of Seattle has added multifamily buildings to the list of those required to comply with HVAC System Performance approach.

The 2018 WSEC established baseline HVAC system specifications for the four covered building types. This was done by convening a stakeholder group that included, in addition to the authors, mechanical engineers, energy modelers, energy code developers, and code enforcement officials working in Washington State [14]. The approach used by the group to choose the system configurations included the following considerations:

1. System configurations should include efficient, proven approaches that have been successfully installed in these building types in Washington State.

2. Heating should be provided by heat pump technology.

3. Space conditioning systems should include a fan that cycles on and off to meet loads and a separate dedicated outdoor air system (DOAS) that includes sensible energy recovery.

4. All system parameters should at least meet prescriptive code requirements and exceed those requirements where standard practice dictates. For example, fan power and sensible recovery effectiveness are better than required prescriptively.

Unique baseline system properties have been defined for small office $\left(<50,000 \mathrm{ft}^{2}\right)$, large office $\left(\geq 50,000 \mathrm{ft}^{2}\right)$, retail, school and library building types. The large office baseline system is specified as cycling water source heat pumps (WSHPs) with prescribed values for heat pump heating and cooling efficiency, pump power, fan power, etc. combined with 
a DOAS with energy recovery. Baseline systems for all other building types are specified as cycling air source heat pumps (ASHPs) with a DOAS with energy recovery. Outside air economizers are specified for the retail and school building types. Table 2 summarizes the baseline systems.

Table 2. WSEC specifications for baseline HVAC systems (WSEC 2018).

\begin{tabular}{|c|c|c|c|c|}
\hline Building Type Parameter & Large Office & Small Office & Retail & School \\
\hline System Type & $\begin{array}{l}\text { Water-source heat } \\
\text { pump }\end{array}$ & $\begin{array}{l}\text { Packaged air-source } \\
\text { heat pump }\end{array}$ & $\begin{array}{l}\text { Packaged air-source } \\
\text { heat pump }\end{array}$ & $\begin{array}{l}\text { Packaged air-source } \\
\text { heat pump }\end{array}$ \\
\hline \multicolumn{5}{|c|}{ Primary Heating and Cooling System } \\
\hline Fan Control & Cycle on load & Cycle on load & Cycle on load & Cycle on load \\
\hline Space Condition Fan Power & $\begin{array}{c}0.528 \mathrm{~W} / \mathrm{CFM} \\
\left(1119 \mathrm{~W} \text { per m } \mathrm{m}^{3} / \mathrm{s}\right)\end{array}$ & $\begin{array}{c}0.528 \mathrm{~W} / \mathrm{CFM} \\
(1119 \mathrm{~W} \text { per m³ } / \mathrm{s})\end{array}$ & $\begin{array}{c}0.522 \mathrm{~W} / \mathrm{CFM} \\
(1106 \mathrm{~W} \text { per m³ } / \mathrm{s})\end{array}$ & $\begin{array}{c}0.528 \mathrm{~W} / \mathrm{CFM} \\
(1119 \mathrm{~W} \text { per m³ } / \mathrm{s})\end{array}$ \\
\hline Fan Total Static Pressure & $\begin{array}{l}2.5^{\prime \prime} \text { in w.g. } \\
(622.7 \mathrm{~Pa})\end{array}$ & $\begin{array}{l}2.5^{\prime \prime} \text { in w.g. } \\
(622.7 \mathrm{~Pa})\end{array}$ & $\begin{array}{l}2.5^{\prime \prime} \text { in w.g. } \\
(622.7 \mathrm{~Pa})\end{array}$ & $\begin{array}{l}2.5^{\prime \prime} \text { in w.g. } \\
(622.7 \mathrm{~Pa})\end{array}$ \\
\hline Fan/Motor Efficiency & $65 \% / 85.5 \%$ & $65 \% / 85.5 \%$ & $65 \% / 86.5 \%$ & $65 \% / 85.5 \%$ \\
\hline Supplemental Heating Availability & NA & $<40^{\circ} \mathrm{F}\left(<4.4^{\circ} \mathrm{C}\right)$ & $<40^{\circ} \mathrm{F}\left(<4.4^{\circ} \mathrm{C}\right)$ & $<40^{\circ} \mathrm{F}\left(<4.4^{\circ} \mathrm{C}\right)$ \\
\hline $\begin{array}{l}\text { Unit Size as Basis for Efficiency } \\
\text { (Cooling) }\end{array}$ & $\begin{array}{c}17-65 \mathrm{MBh} \\
(4982-19,050 \mathrm{~W})\end{array}$ & $\begin{array}{l}<65 \mathrm{MBh} \\
(19,050 \mathrm{~W})\end{array}$ & $\begin{array}{c}65-135 \mathrm{MBh} \\
(19,050-39,565 \mathrm{~W})\end{array}$ & $\begin{array}{l}<65 \mathrm{MBh} \\
(19,050 \mathrm{~W})\end{array}$ \\
\hline Cooling COP (Net of fan) ${ }^{a}$ & 4.46 & 3.83 & 4.25 & 3.83 \\
\hline Heating COP (Net of fan) ${ }^{a}$ & 4.61 & 3.81 & 3.57 & 3.81 \\
\hline Cooling Source & DX (heat pump) & DX (heat pump) & DX (heat pump) & DX (heat pump) \\
\hline Heat Source & Heat Pump & Heat Pump & Heat Pump & Heat Pump \\
\hline Cooling Tower Efficiency & $\begin{array}{c}40.2 \mathrm{GPM} / \mathrm{HP} \\
\left(3.401 \mathrm{~m}^{3} / \mathrm{s} \text { per } \mathrm{MW}\right)\end{array}$ & NA & NA & NA \\
\hline $\begin{array}{l}\text { WSHP Loop Heat Source, } \\
\text { Efficiency }\end{array}$ & Gas Boiler, $80 \%$ Et & NA & NA & NA \\
\hline WSHP Loop Heat Rejection ${ }^{c}$ & Cooling Tower & NA & NA & NA \\
\hline WSHP Loop Temperature Control & $\begin{array}{c}50^{\circ} \mathrm{F} \text { to } 70^{\circ} \mathrm{F} \\
\left(10^{\circ} \mathrm{C} \text { to } 21.1^{\circ} \mathrm{C}\right)\end{array}$ & & & \\
\hline WSHP Cooling Tower Efficiency & $\begin{array}{l}40.2 \mathrm{GPM} / \mathrm{HP} \\
\left(3.401 \mathrm{~m}^{3} / \mathrm{MJ}\right)\end{array}$ & NA & NA & NA \\
\hline WSHP Pump Power (W/GPM) & $\begin{array}{c}16.1 \mathrm{~W} / \mathrm{GPM} \\
\left(353,605 \mathrm{~W} \text { per } \mathrm{m}^{3} / \mathrm{s}\right)\end{array}$ & NA & NA & NA \\
\hline Pump Head & $\begin{array}{c}60 \mathrm{ft} \\
(179.3 \mathrm{kPa})\end{array}$ & NA & NA & NA \\
\hline Pump Efficiency/Motor Efficiency & $78 \% / 90 \%$ & NA & NA & NA \\
\hline WSHP Loop Pumping Control & VSD Pump & NA & NA & NA \\
\hline Outside Air Economizer b & No & No & Yes & Yes \\
\hline ERV (Yes/No/NA) & NA & NA & NA & NA \\
\hline DCV (Yes/No) & No & No & No & No \\
\hline \multicolumn{5}{|c|}{ Ventilation System } \\
\hline Occupied Ventilation Source & DOAS & DOAS & DOAS & DOAS \\
\hline Total DOAS Fan Power (W/CFM) & $\begin{array}{c}0.819 \mathrm{~W} / \mathrm{CFM} \\
\left(1735 \mathrm{~W} \text { per } \mathrm{m}^{3} / \mathrm{s}\right)\end{array}$ & $\begin{array}{c}0.819 \mathrm{~W} / \mathrm{CFM} \\
\left(1735 \mathrm{~W} \mathrm{per} \mathrm{m}^{3} / \mathrm{s}\right)\end{array}$ & $\begin{array}{c}0.730 \mathrm{~W} / \mathrm{CFM} \\
\left(1547 \mathrm{~W} \text { per m } \mathrm{m}^{3} / \mathrm{s}\right)\end{array}$ & $\begin{array}{c}0.742 \mathrm{~W} / \mathrm{CFM} \\
(1572 \mathrm{~W} \text { per m³ } / \mathrm{s})\end{array}$ \\
\hline $\begin{array}{l}\text { DOAS Fan Total Static Pressure, in. } \\
\text { w.g. (Each Air Stream) }\end{array}$ & $\begin{array}{c}1.84^{\prime \prime} \\
(458.3 \mathrm{~Pa})\end{array}$ & $\begin{array}{c}1.84^{\prime \prime} \\
(458.3 \mathrm{~Pa})\end{array}$ & $\begin{array}{c}1.84^{\prime \prime} \\
(458.3 \mathrm{~Pa})\end{array}$ & $\begin{array}{c}1.84^{\prime \prime} \\
(458.3 \mathrm{~Pa})\end{array}$ \\
\hline
\end{tabular}


Table 2. Cont

\begin{tabular}{lcccc}
\hline \multicolumn{1}{c}{ Building Type Parameter } & Large Office & Small Office & Retail & School \\
\hline $\begin{array}{l}\text { DOAS or Ventilation Fan/Motor } \\
\text { Efficiency }\end{array}$ & $65.0 \% / 81.1 \%$ & $65.0 \% / 81.1 \%$ & $65.0 \% / 91.0 \%$ & $65.0 \% / 89.5 \%$ \\
\hline DOAS Sensible Effectiveness & $70 \%$ & $70 \%$ & $70 \%$ & $70 \%$ \\
\hline DOAS Supplemental heat/cool & No & No & Wild & Bypass \\
\hline $\begin{array}{l}\text { DOAS Supply Temperature } \\
\text { Control d }\end{array}$ & Bypass & No & Yes & Bypass \\
\hline DOAS ERV Economize Lockout & Yes & Yes \\
\hline
\end{tabular}

${ }^{a}$ COPs shown are direct heating or cooling performance and do not include fan energy use. Standard 90.1-2019 Appendix G (G3.1.2.1) provides the process for separation of fan power from COP in packaged equipment for units where the efficiency rating includes fan energy (e.g., SEER, EER, HSPF, COP). ${ }^{b}$ Economizer high limit is be based on differential dry-bulb control. DOAS system continues to operate during economizer mode. ${ }^{\mathrm{C}}$ Includes a single axial fan cooling tower with variable-speed fans at $40.2 \mathrm{GPM} / \mathrm{HP}$, sized for an approach of $10^{\circ} \mathrm{F}$ and a range of $10^{\circ} \mathrm{F}$. "Wild" DOAS control indicates no active control of the supply air temperature leaving the DOAS system. Temperature will fluctuate based only on entering and leaving conditions and the effectiveness of ERV. "Bypass" DOAS control includes modulating dampers to bypass ERV with the intent to maintain supply air temperature at a maximum of $60^{\circ} \mathrm{F}$ when outside air is below $75^{\circ} \mathrm{F}$. Once outside air is above $75^{\circ} \mathrm{F}$ bypass dampers will be fully closed. Abbreviations: CFM: cubic feet per minute; GPM: gallons per minute; HP: horsepower; DX: direct expansion; COP: coefficient of performance; Et: thermal efficiency.

\section{HVAC System Performance Implementation in the Building Energy Asset Score Tool}

The 2018 WSEC specifies the requirements for defining the proposed and baseline building for TSPR compliance analysis and defines requirements for simulation tools that would implement the HVAC System Performance ruleset but does not require a specific tool. The HVAC System Performance ruleset was implemented into DOE's Building Energy Asset Score tool to provide a TSPR compliance module (HVAC System Performance tool) for WSEC compliance analysis.

The Building Energy Asset Score Tool (Asset Score Tool), developed by PNNL for the U.S. Department of Energy (DOE), is a web-based tool to assess the as-designed efficiency of buildings. It uses a simplified modeling approach to assess the efficiency of a building's energy-related system, to encourage investment in cost-effective improvements by building owners and managers [24,25]. Asset Score Tool uses EnergyPlus and OpenStudio to develop a whole building energy model of a building and provides an assessment of building systems based on the specified building characteristics [21,26]. It has a simplified user interface that allows a user to define their building characteristics and runs whole building energy simulation using standard operating assumptions to generate an Asset Score for the user's building. The tool also identifies upgrade opportunities for energy savings and a corresponding 'potential' Asset Score. An additional module has been added to the Asset Score tool for TSPR analysis which allows a user to define their proposed building design in the tool in accordance with the ruleset proposed for the 2018 WSEC and automatically generate the baseline design following the rules defined in the code [14]. The following sections explain the tool workflow for defining the proposed building and generating compliance results.

\subsection{Asset Score Tool Architecture}

The Asset Score tool provides a simplified user interface for a user to define their proposed building design and automatically generates the baseline building based on the rules defined in the 2018 WSEC for compliance analysis. It also generates a PDF report which includes the compliance results and additional details about the building for a code official to verify against design drawings. The core components of the Asset Score Tool application are functionally separated into the following four subsystems: (i) user interface that allows a user to define the properties of the building; (ii) Asset Score Application that stores all user inputs in a database and translates this information into the Asset Score data model; (iii) modeling engine that can take in the Asset Score data model and generate the 
corresponding OpenStudio models for simulation using EnergyPlus; (iv) report generator that post-processes the simulation results. The TSPR module has been built on top of the Asset Score tool structure and adds the capability to automatically generate the baseline building based on the rules defined in the WSEC.

\subsection{HVAC System Performance Analysis Workflow}

The Asset Score Application's web interface allows users to define their building geometry, envelope, HVAC, and lighting systems. For a TSPR analysis, certain values are prescribed, and automatically defaulted based on the code requirement. For example, the 2018 WSEC prescribes the lighting power density and infiltration rate, which are automatically added by the tool. The overall tool workflow is shown in Figure 2. User specified values, in conjunction with the ruleset's default values provide for the required inputs for constructing an OpenStudio simulation model. The Asset Score Modeling Engine ingests these inputs to generate three separate analyses used to calculate a TSPR: the ideal loads run, sizing run and the annual run.

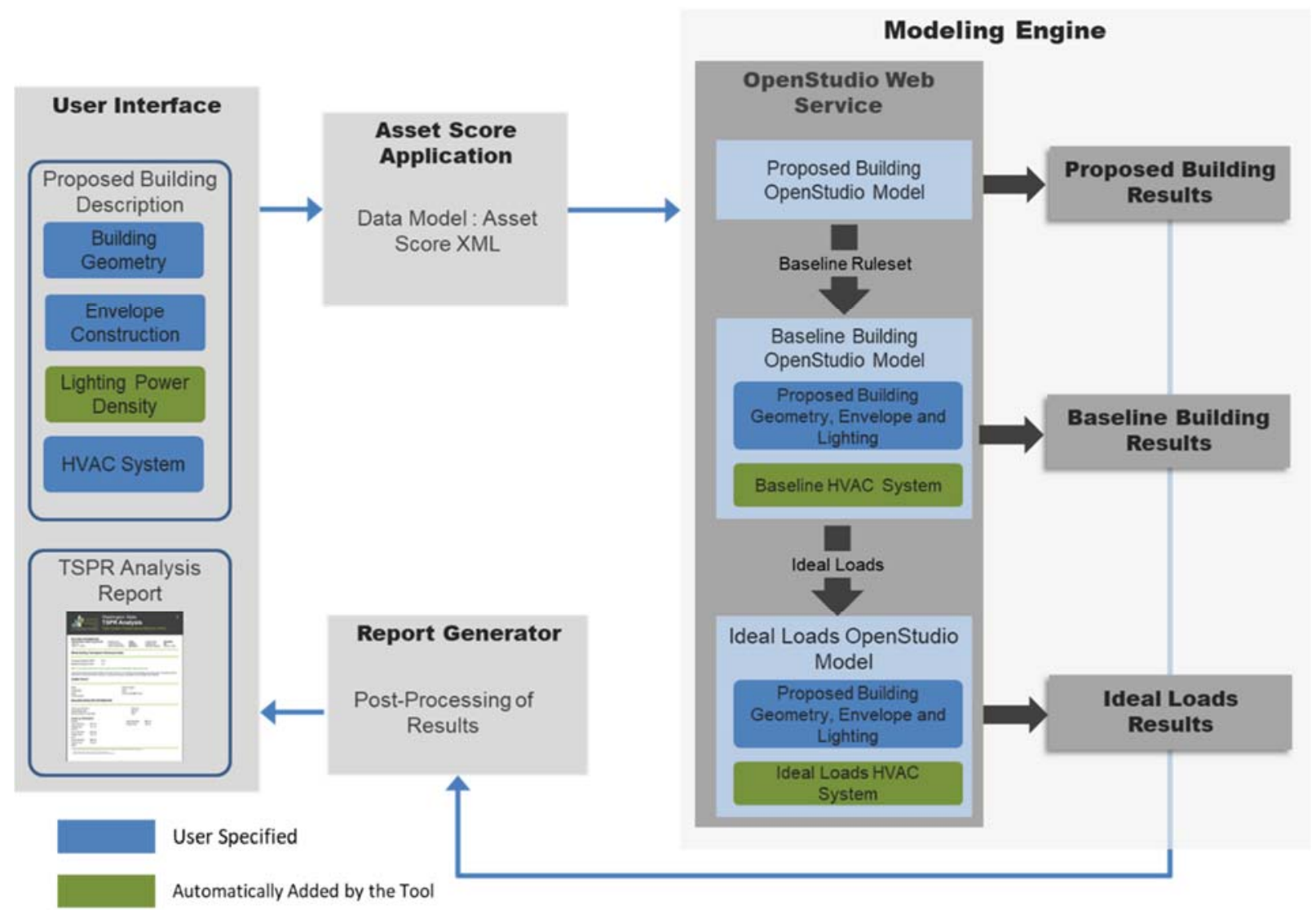

Figure 2. HVAC System Performance tool structure for HVAC System Performance analysis.

The ideal loads analysis calculates the annual heating and cooling loads of the building. The sizing run calculates the design system capacities and flow rates used to inform values for certain parameters in the annual run (e.g., cooling tower fan power, minimum airflow fraction for VAV with reheat terminals). Lastly, the annual run calculates the annual energy use by end use for the entire building. These three analyses are done for both proposed and baseline buildings. The proposed run represents a user's inputs as entered in the Asset Score Application. The baseline run is identical to the proposed building in terms of its geometry, envelope construction, internal loads and ventilation loads but with a WSEC's baseline HVAC system in place of the user's HVAC system. The report generator ingests the simulation outputs and calculates the TSPR for the proposed and baseline building. 
Outputs are written to a PDF report documenting the calculated baseline and proposed TSPRs along with all model inputs defined by the user in the user interface.

\section{Validation of the HVAC System Performance Approach and the Simplified Analysis Tool}

As previously discussed, the HVAC System Performance tool provides a simplified modeling approach and implements the TSPR ruleset for evaluating the HVAC system performance. The simplified modeling approach is provided through several capabilities including a simpler approach for representing building geometry, standard defaults for building schedules and loads, combining like HVAC systems, defaults for equipment properties and controls, etc. These simplifications can result in variation in simulation results and the results seen through the simplified approach need to be validated to verify the impact of the simplifications. Similarly, the HVAC System Performance ruleset, as defined for WSEC, should be able to screen out HVAC systems that would otherwise meet prescriptive requirements and encourage high performance HVAC system design through efficiency and/or controls which go beyond the prescriptive minimum requirements. Both requirements were validated through two sets of analyses.

The first set of analysis aimed at comparing the simplified model generated using the HVAC System Performance tool against a more detailed model to identify the impact of the simplifications. The detailed models used in this case were the prototype building models generated for WSEC analysis. The prototype building models were originally developed for DOE to assess the relative improvement of sequential versions of ASHRAE Standard 90.1. They represent about $75 \%$ of the commercial building floor area in the United States for new construction, including both commercial buildings and mid- to high-rise residential buildings [23,27]. The HVAC systems in each prototype were selected based on standard "good design practice" for each building type. The characteristics of the prototype buildings are well documented, and the models are readily available online [28]. The Standard 90.1 Prototypes were modified to represent WSEC requirements. The WSEC prototypes were compared with the simpler versions of the same buildings generated using the HVAC System Performance tool to identify the variation in energy savings and absolute energy use introduced due to the simplifications. The second set of analysis evaluates the effectiveness of the HVAC System Performance approach in screening out minimally code-compliant buildings to give credit to higher equipment efficiency or efficient HVAC system controls. Both sets of analysis are discussed in the sections below.

\subsection{Validation of the Simplified Energy Modeling Approach}

The purpose of the simplification validation is to identify the variability in simulation results arising due to the simplified modeling approach including uniform distribution of internal loads, simplified thermal zoning, simplifications in building geometry representation etc. These tests were carried out using PNNL prototype building models [28].

The prototype building models for small office, large office, primary school and standalone retail were modified to include the WSEC requirements for each of the respective use types. The modifications included changes to the HVAC systems to match those specified by the WSEC. For example, the original prototype building model for the large office has a variable air volume system with hot water reheat and chilled water produced by a natural gas boiler and water-cooled chiller. The WSEC specifies the baseline for the large office as a dedicated outdoor air system (DOAS) with energy recovery ventilation (ERV) with a water loop heat pump (WLHP). Heat is added or rejected from the water loop by a natural gas boiler and open circuit cooling tower as needed. Simplified versions of the WSEC prototypes were then generated using the HVAC System Performance tool attempting to match the more complex versions to the extent possible with the HVAC System Performance tool. The detailed WSEC prototype was then compared against the simple WSEC prototype to identify the degree of variation in energy use by end use. Variations in energy use are expected due to the reasons discussed below. 


\subsubsection{Model Geometry and Thermal Zoning Simplifications}

The HVAC System Performance tool uses 'multiple blocks' to create a simplified geometric representation of the building. A block, for the purpose of the HVAC System Performance tool, can include one or more thermal zones. It can represent the whole building or a portion of a building with the same use type and served by the same HVAC system type. The HVAC System Performance ruleset in the WSEC requires each floor in a block to be modeled with a perimeter and core zone layout if the length of a surface exceeds $45^{\prime}$. Following this guideline, the simplified model is specified as perimeter and core thermal zone layout which differs from the actual thermal zone layout in the detailed WSEC prototype building model, as shown in Figures 3 and 4.

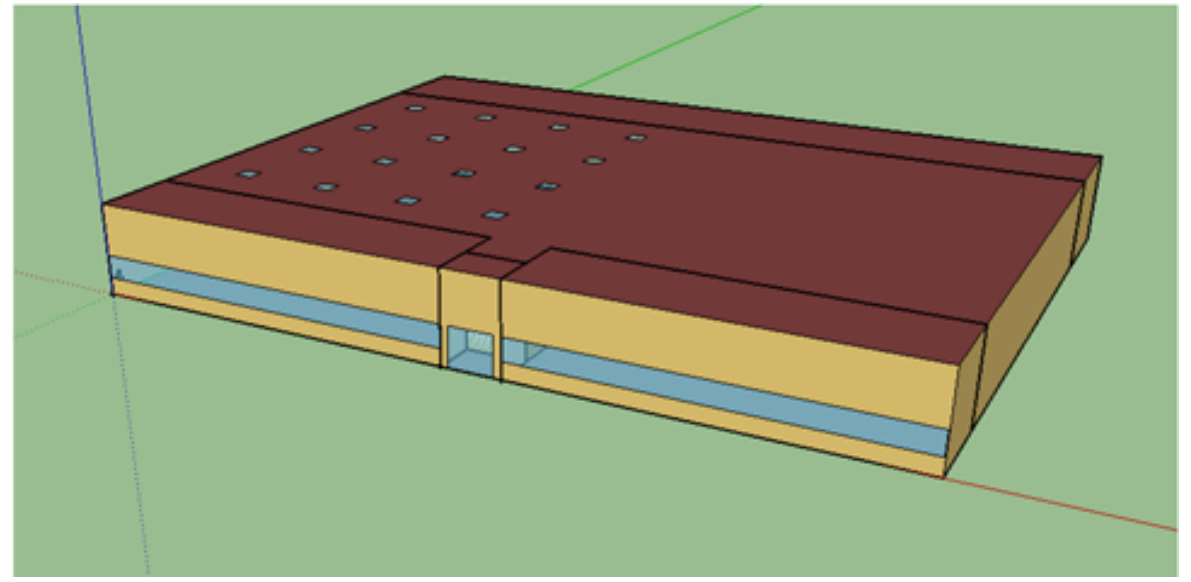

Figure 3. Detailed geometry for the retail standalone prototype building model.

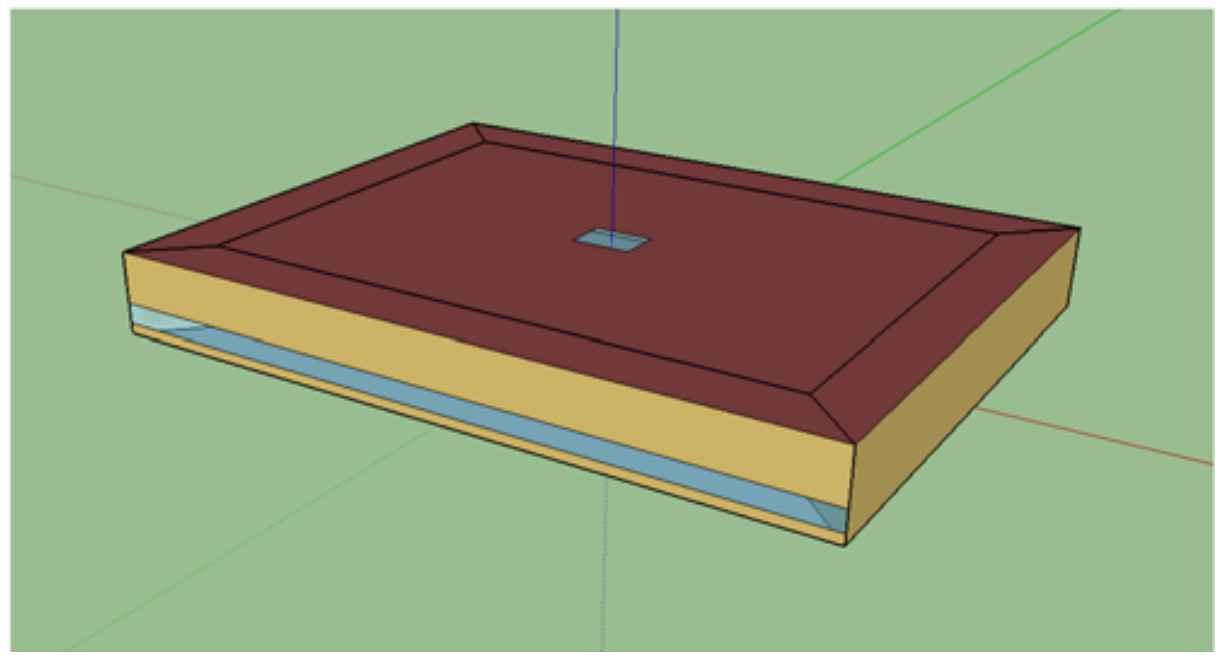

Figure 4. Simplified geometry analyzed by TSPR analysis tool for the retail standalone prototype building model.

WSEC defines acceptable limits for variations in opaque surface area and fenestration area which might be introduced due to the simplified geometric representation of the building. The energy impact of these simplifications is also evaluated through this analysis.

\subsubsection{Schedules}

HVAC System Performance tool uses standard operational schedules based on the building type, unlike the detailed energy model which in some cases has a space-by-space definition of schedules. The standard operation assumptions and loads are based on 
values defined in ASHRAE Standard 90.1 Appendix C [3]. Prototypes use a space-by-space method for defining schedules. This simplification affects the zone level loads and hence the HVAC energy consumption.

\subsubsection{Internal Loads}

Internal loads, including plug and process loads, lighting loads, occupant loads, and ventilation loads are modeled as a uniformly distributed equipment power density in the HVAC System Performance tool. Detailed prototype buildings have specific spaces and zones for different functions, like conference rooms, corridors, lobbies, etc. with their corresponding occupant, lighting and plug loads. Though the building level loads, as defined in Standard 90.1 Appendix C are based on specific space type distribution for each use type, the simplification does result in variations in the energy use between the WSEC prototype and the TSPR model.

\subsubsection{HVAC}

TSPR analysis tool simplifies the process for modeling HVAC systems by requiring a user to define a single geometric block for contiguous spaces of the same use type and served by the same type of HVAC system. If these blocks include multiple pieces of equipment of varying capacities and efficiencies, the tool automatically calculates a capacity weighted average efficiency and design airflow weighted average fan power which is used in the simulation analysis. Similarly, for plant loops with multiple pumps, a design water flow weighted average pump power is calculated and used in the analysis.

The section below shows the energy use by end use results for the detailed and simplified stand-alone retail prototype. As discussed above, variations in energy use intensity are expected between the detailed and simplified model due to the inherent differences in space-by-space loads versus uniform building level loads, different schedules of operation, simplified thermal zoning and other model simplifications. As a comparative analysis, the HVAC system performance approach compares the TSPR for the proposed building against a baseline building, both of which are developed using the simplified approach. Hence, the absolute variation of energy use by end use between the detailed and simplified models is less important than the relative variation.

To isolate the impact of model simplifications, the space loads were adjusted proportionately for all spaces, so that the overall energy consumption due to internal loads was similar for the detailed and simplified models. Results are shown below for the original WSEC prototype as well as the modified WSEC prototype. As shown in Figure $5 a, b$, the model simplifications result in $~ 20 \%$ higher heating and cooling energy use in the TSPR prototype when compared to the modified WSEC prototype. A similar variation is noticed in the ideal loads, as shown in Figure $6 a, b$, when the detailed WSEC prototype is compared against the simpler TSPR prototype. The TSPR (using carbon emissions) for the TSPR prototype is 12.7 and for the WSEC prototype is 12.9. This is a small variation due to model simplifications and supports the use of a simplified modeling approach. 
WSEC Prototype Compared to TSPR Prototype (Energy Use by End Use)

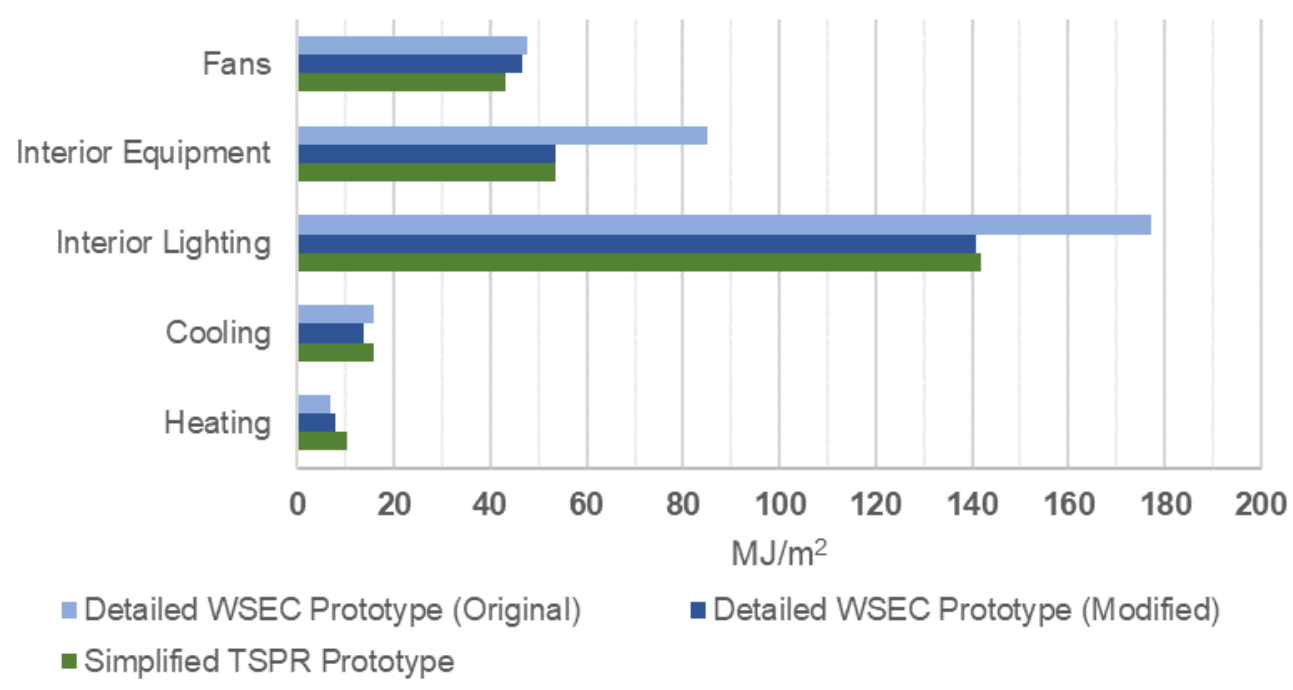

(a)

\section{WSEC Prototype Compared to TSPR Prototype (Energy Use by End Use)}

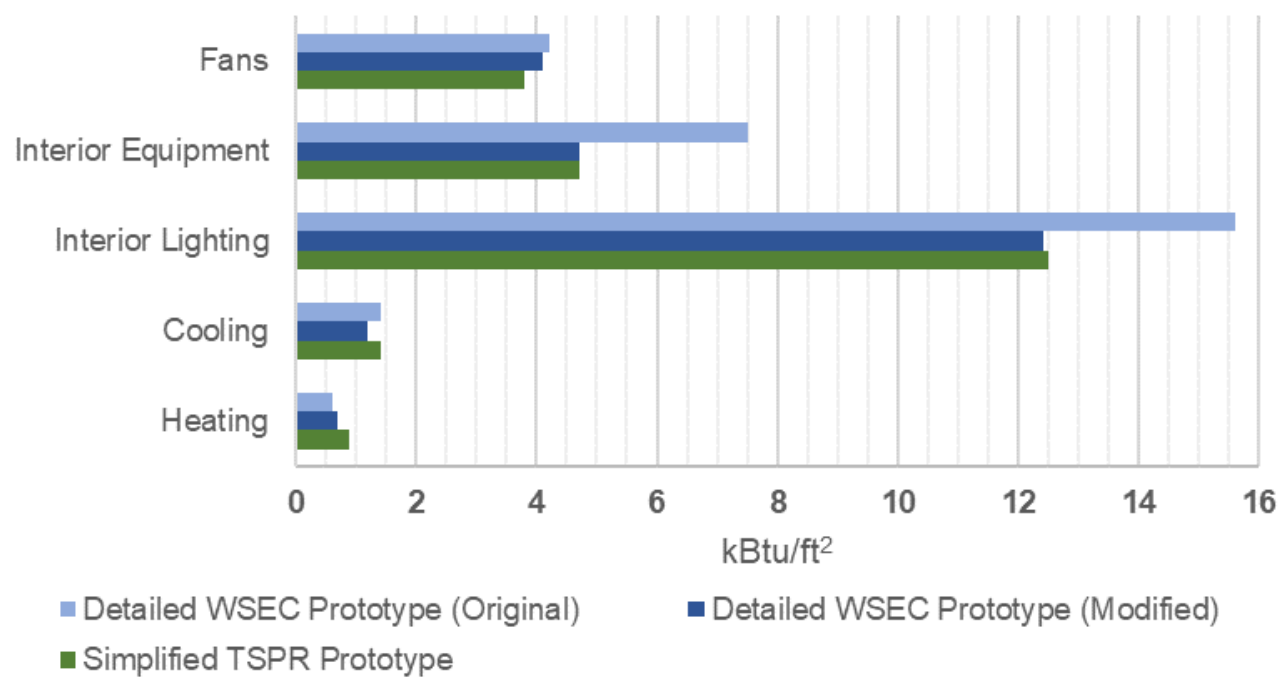

(b)

Figure 5. Energy use by end use comparison of the detailed prototype versus simplified TSPR model. (a) SI units; (b) IP units. 


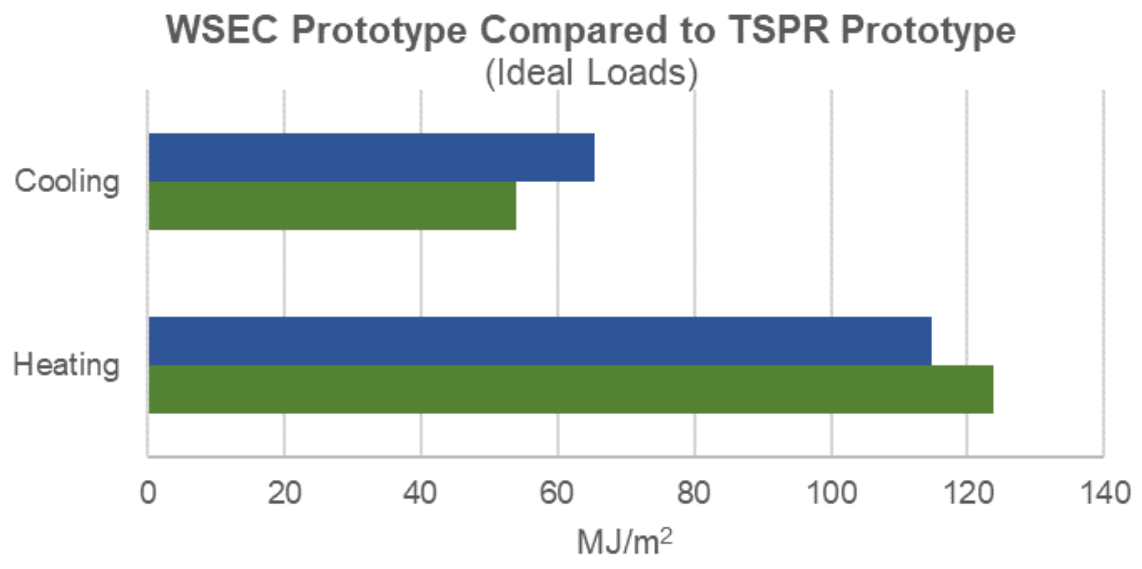

- Detailed WSEC Prototype (Modified) a Simplified TSPR Prototype

(a)

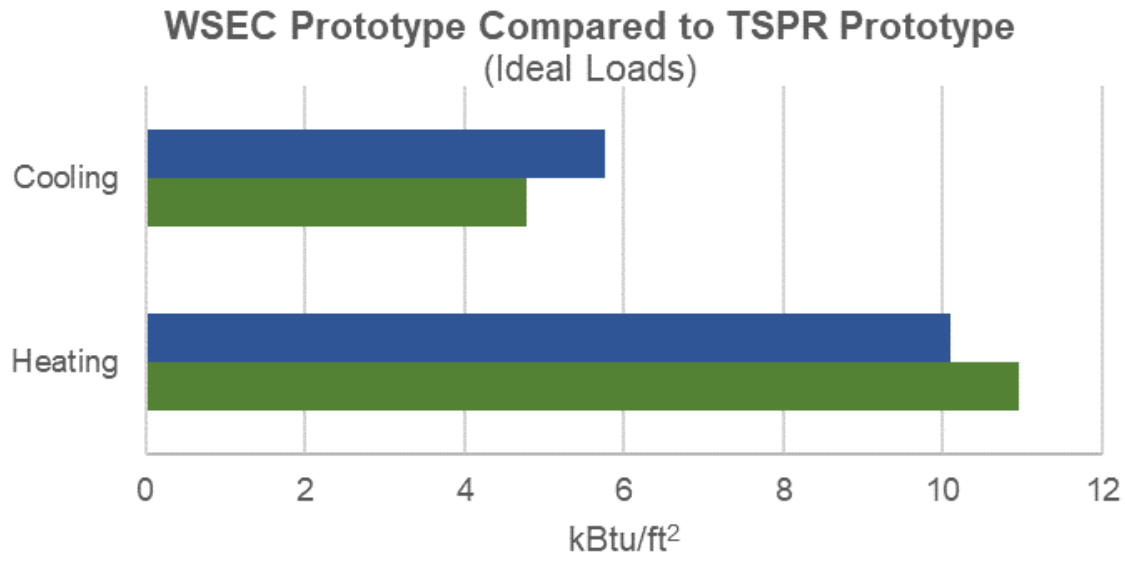

- Detailed WSEC Prototype (Modified) @ Simplified TSPR Prototype

(b)

Figure 6. Annual heating and cooling loads comparison of the detailed prototype versus simplified TSPR model. (a) SI units; (b) IP units.

\subsection{Validation of the TSPR Approach}

To validate the effectiveness of the TSPR approach for identifying efficient system configurations, several HVAC system configurations were analyzed. Each system configuration was modeled as a minimal prescriptive compliant system as well as a highperformance version of the same with slightly better performance than the minimum prescriptive requirements. This test aimed at verifying that the baseline systems identified for each use type performed better than the minimally code compliant version of the test models, rewarded efficient system configurations, and system controls. The results for a large office and a retail building are shown below. As previously discussed, WSEC uses carbon emissions as the metric for compliance and the emissions factors shown in Table 1 reflect the large amount of hydroelectric power contributing to the Washington State electric grid. Hence gas-fired heating systems need additional efficiency improvements compared to electric heating systems to comply with code. The description of each system is provided in Tables 3 and 4 for large office and retail, respectively.

The high-performance versions of the minimally compliant cases were first defined by using engineering judgment to identify building components that can directly impact the performance of each prototype building. Then, hundreds of parametric simulations 
were carried out where the efficiency level of each component previously identified was varied individually or as a bundle. For convenience, these simulations were performed outside of the TSPR tool which currently does not have a parametric analysis feature, but the simulation results are equivalent to those generated by the TSPR tool. The simulation input files were generated using a script written in the Python programming language and simulations were run using the EnergyPlus software alone. The TSPR of each of these high-performance cases were then compared with the corresponding WSEC baseline TSPR. The main goal of this exercise was to ensure that most of the high-performance cases complying with the code would be allowed and that compliant designs did not consistently require top tier performance for each building component, making them prohibitively expensive. Moreover, this exercise provided some insight on the level of stringency of the WSEC code baselines for each occupancy types as defined by the stakeholder group. While this was not the case for the WSEC, a similar simulation-based parametric analysis could be used to define the code baseline for each occupancy type in future code development.

Table 3. System configurations for a large office building analyzed using HVAC System Performance tool.

\begin{tabular}{|c|c|c|c|c|c|c|c|}
\hline \multirow{2}{*}{\begin{tabular}{l}
\multicolumn{1}{c}{ System Type } \\
TSPR Results \\
$\left(\mathrm{kBtu} / \mathrm{lb}-\mathrm{CO}_{2}\right)$
\end{tabular}} & \multirow{2}{*}{$\begin{array}{l}\begin{array}{c}\text { Baseline: DOAS + } \\
\text { WLHP }\end{array} \\
11.71\end{array}$} & \multicolumn{2}{|c|}{ DOAS + FCU } & \multicolumn{2}{|c|}{ VAV with HW Reheat } & \multicolumn{2}{|c|}{ VAV with Electric Reheat } \\
\hline & & 10.03 & 11.89 & 11.17 & 13.73 & 9.52 & 12.87 \\
\hline $\begin{array}{l}\text { Heating Source, } \\
\text { Efficiency }\end{array}$ & Heat Pump, 4.61 COP & Boiler, $80 \%$ & Boiler, $96 \%$ & Boiler, $80 \%$ Et & Boiler, $93 \%$, Et & $\begin{array}{l}\text { Electric Resistance } \\
\text { Furnace, } 100 \% \mathrm{Et}\end{array}$ & $\begin{array}{l}\text { Electric Resistance } \\
\text { Furnace, } 100 \% \mathrm{Et}\end{array}$ \\
\hline Boiler Pump Power & NA & $\begin{array}{l}\text { 16 W/GPM } \\
\left(253,605 \mathrm{~W}_{\text {per m}}^{3} / \mathrm{s}\right)\end{array}$ & $\begin{array}{l}12.8 \mathrm{~W} / \mathrm{GPM} \\
(202,900 \mathrm{~W} \text { per m } 3 / \mathrm{s})\end{array}$ & $\begin{array}{l}16 \mathrm{~W} / \mathrm{GPM} \\
\left(253,605 \mathrm{~W}_{\text {per m}}{ }^{3} / \mathrm{s}\right)\end{array}$ & $\begin{array}{l}16 \mathrm{~W} / \mathrm{GPM} \\
\left(253,605 \mathrm{~W} \text { per m }{ }^{3} / \mathrm{s}\right)\end{array}$ & NA & NA \\
\hline $\begin{array}{l}\text { Cooling Source, } \\
\text { Efficiency }\end{array}$ & DX, $4.46 \mathrm{COP}$ & $\begin{array}{l}\text { Air Cooled Chiller, } \\
2.843 \text { COP }\end{array}$ & $\begin{array}{l}\text { Air Cooled Chiller, } \\
3.077 \text { COP }\end{array}$ & $\begin{array}{l}\text { Water Cooled Chiller, } \\
6.1 \mathrm{COP}\end{array}$ & $\begin{array}{l}\text { Water Cooled Chiller, } \\
6.1 \mathrm{COP}\end{array}$ & $\begin{array}{l}\text { Water Cooled Chiller, } \\
6.1 \mathrm{COP}\end{array}$ & $\begin{array}{l}\text { Water Cooled Chiller, } \\
6.1 \mathrm{COP}\end{array}$ \\
\hline $\begin{array}{l}\text { Primary Chiller Pump } \\
\text { Control, Pump Power }\end{array}$ & $\mathrm{NA}$ & $\begin{array}{l}\text { Constant Primary, } \\
4 \mathrm{~W} / \mathrm{GPM}(63 \\
\left.401 \mathrm{~W}_{\text {per m}}^{3} / \mathrm{s}\right)\end{array}$ & $\begin{array}{l}\text { Constant Primary, } \\
3.2 \mathrm{~W} / \mathrm{GPM} \\
\left(50,700 \mathrm{~W} \text { per m} \mathrm{m}^{3} / \mathrm{s}\right)\end{array}$ & $\begin{array}{l}\text { Constant Primary, } \\
4 \mathrm{~W} / \mathrm{GPM}(63 \\
\left.401 \mathrm{~W} \text { per m }{ }^{3} / \mathrm{s}\right)\end{array}$ & $\begin{array}{l}\text { Constant Primary, } \\
3.2 \mathrm{~W} / \mathrm{GPM} \\
\left(50,700 \mathrm{~W} \text { per m } \mathrm{m}^{3} / \mathrm{s}\right)\end{array}$ & $\begin{array}{l}\text { Constant Primary, } \\
4 \mathrm{~W} / \mathrm{GPM} \\
\left(63,401 \mathrm{~W} \text { per m} \mathrm{m}^{3} / \mathrm{s}\right)\end{array}$ & 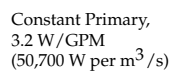 \\
\hline $\begin{array}{l}\text { Secondary Chiller } \\
\text { Pump Control, Pump } \\
\text { Power }\end{array}$ & & $\begin{array}{l}\text { Variable Secondary, } \\
12 \mathrm{~W} / \mathrm{GPM} \\
\left(190,204 \mathrm{~W} \text { per m }{ }^{3} / \mathrm{s}\right)\end{array}$ & $\begin{array}{l}\text { Variable Secondary, } \\
10.8 \mathrm{~W} / \mathrm{GPM} \\
\left(171,200 \mathrm{~W} \text { per m }{ }^{3} / \mathrm{s}\right)\end{array}$ & $\begin{array}{l}\text { Variable Secondary, } \\
12 \mathrm{~W} / \mathrm{GPM} \\
\left(190,204 \mathrm{~W} \text { per m} \mathrm{m}^{3} / \mathrm{s}\right)\end{array}$ & $\begin{array}{l}\text { Variable Secondary, } \\
10.8 \mathrm{~W} / \mathrm{GPM} \\
(171,200 \mathrm{~W} \text { per m } \\
3\end{array}$ & $\begin{array}{l}\text { Variable Secondary, } \\
12 \mathrm{~W} / \mathrm{GPM} \\
\left(190,204 \mathrm{~W} \text { per m }{ }^{3} / \mathrm{s}\right)\end{array}$ & $\begin{array}{l}\text { Variable Secondary, } \\
10.8 \mathrm{~W} / \mathrm{GPM} \\
\left(171,200 \mathrm{~W} \text { per m }{ }^{3} / \mathrm{s}\right)\end{array}$ \\
\hline $\begin{array}{l}\text { Cooling Tower } \\
\text { Efficiency }\end{array}$ & & NA & NA & $\begin{array}{l}40.2 \mathrm{GPM} / \mathrm{HP} \\
\left(3.401 \mathrm{~m}^{3} / \mathrm{s} \text { per MW }\right)\end{array}$ & $\begin{array}{l}40.2 \mathrm{GPM} / \mathrm{HP} \\
\left(3.401 \mathrm{~m}^{3} / \mathrm{s} \text { per MW }\right)\end{array}$ & $\begin{array}{l}40.2 \mathrm{GPM} / \mathrm{HP} \\
\left(3.401 \mathrm{~m}^{3} / \mathrm{sper} \mathrm{MW}\right)\end{array}$ & $\begin{array}{l}40.2 \mathrm{GPM} / \mathrm{HP} \\
\left(3.401 \mathrm{~m}^{3} / \mathrm{s} \text { per MW) }\right.\end{array}$ \\
\hline $\begin{array}{l}\text { Fan Control, Fan Power } \\
\text { (W/CFM) }\end{array}$ & On-Off, $0.528 \mathrm{~W} / \mathrm{CFM}$ & On-Off, 0.25 W/CFM & On-Off, 0.16 W/CFM & $\mathrm{VAV}, 1.135 \mathrm{~W} / \mathrm{CFM}$ & $\mathrm{VAV}, 1.021 \mathrm{~W} / \mathrm{CFM}$ & $\mathrm{VAV}, 1.135 \mathrm{~W} / \mathrm{CFM}$ & VAV, 0.9825 W/CFM \\
\hline Reheat Source & NA & NA & $\mathrm{NA}$ & HW Reheat & HW Reheat & Electric Reheat & Electric Reheat \\
\hline $\begin{array}{l}\text { Minimum Airflow } \\
\text { Fraction }\end{array}$ & NA & NA & NA & 0.3 & 0.2 & 0.3 & 0.2 \\
\hline Economizer Control & NA & No & No & Yes (90\% Effectiveness) & Yes (90\% Effectiveness) & Yes ( $90 \%$ Effectiveness) & Yes ( $90 \%$ Effectiveness) \\
\hline $\operatorname{ERV}(\mathrm{Y} / \mathrm{N})$ & NA & NA & $\mathrm{NA}$ & No & Yes & No & Yes \\
\hline $\begin{array}{l}\text { ERV Sensible, Latent } \\
\text { Effectiveness }\end{array}$ & $\mathrm{NA}$ & NA & NA & NA & $0.70,0.0$ & NA & $0.80,0.60$ \\
\hline DCV Control & No & No & Yes & Yes ( $10 \%$ of Area) & Yes ( $10 \%$ of Area) & Yes $(10 \%$ of Area) & Yes ( $10 \%$ of Area) \\
\hline SAT Reset & NA & NA & NA & Yes (Warmest Zone) & Yes (Warmest Zone) & Yes (Warmest Zone) & Yes (Warmest Zone) \\
\hline $\begin{array}{l}\text { WLHP Cooling Tower } \\
\text { Efficiency }\end{array}$ & $\begin{array}{l}40.2 \mathrm{GPM} / \mathrm{HP} \\
\left(3.401 \mathrm{~m}^{3} / \mathrm{s} \text { per MW) }\right.\end{array}$ & NA & NA & NA & NA & NA & NA \\
\hline WLHP Boiler Efficiency & $80 \% \mathrm{Et}$ & NA & NA & NA & NA & NA & $\mathrm{NA}$ \\
\hline $\begin{array}{l}\text { Coupled with DOAS } \\
\text { System? }\end{array}$ & Yes & Yes & Yes & No & No & No & No \\
\hline $\begin{array}{l}\text { DOAS Cooling Source, } \\
\text { Efficiency }\end{array}$ & No Cooling & No Cooling & No Cooling & NA & NA & NA & $\mathrm{NA}$ \\
\hline $\begin{array}{l}\text { DOAS Heating Source, } \\
\text { Efficiency }\end{array}$ & No Heating & No Heating & No Heating & NA & NA & NA & NA \\
\hline $\begin{array}{l}\text { DOAS Fan Control, Fan } \\
\text { Power }\end{array}$ & $\begin{array}{l}\text { CAV, } \\
0.819 \mathrm{~W} / \mathrm{CFM} \\
\left(1735 \mathrm{~W} \text { per m }{ }^{3} / \mathrm{s}\right)\end{array}$ & $\begin{array}{l}\text { CAV, } \\
0.819 \mathrm{~W} / \mathrm{CFM}^{3} \\
(1735 \mathrm{~W} \text { per m }\end{array}$ & $\begin{array}{l}\text { CAV, } \\
0.737 \text { W/CFM } \\
\left(1562 \mathrm{~W} \mathrm{per} \mathrm{m}^{3} / \mathrm{s}\right)\end{array}$ & NA & NA & NA & NA \\
\hline $\operatorname{ERV}(\mathrm{Y} / \mathrm{N})$ & Yes & Yes & Yes & NA & $\mathrm{NA}$ & NA & NA \\
\hline ERV SAT Control & Yes & Yes & Yes & NA & NA & NA & NA \\
\hline $\begin{array}{l}\text { ERV Sensible, Latent } \\
\text { Effectiveness }\end{array}$ & $0.7,0.0$ & $0.6,0$ & $0.70,0.65$ & NA & NA & NA & NA \\
\hline
\end{tabular}

Abbreviations: CAV: constant air volume; DCV: demand control ventilation; HW Reheat: hot water reheat; SAT: supply air temperature; NA: Not Applicable. 
Table 4. System configurations for a retail building analyzed using HVAC System Performance tool.

\begin{tabular}{|c|c|c|c|c|c|}
\hline \multirow[t]{2}{*}{ System Type } & \multirow{2}{*}{$\begin{array}{c}\text { Baseline: PSZ Heat } \\
\text { Pump + DOAS }\end{array}$} & \multicolumn{2}{|c|}{ Gas Furnace + DOAS } & \multicolumn{2}{|c|}{ DOAS-VRF } \\
\hline & & $\begin{array}{l}\text { Minimum } \\
\text { Requirement }\end{array}$ & High Performance & $\begin{array}{l}\text { Minimum } \\
\text { Requirement }\end{array}$ & High Performance \\
\hline TSPR $\left(\left(\mathrm{kBtu} / \mathrm{lb}-\mathrm{CO}_{2}\right)\right.$ & 13.87 & 11.38 & 14.59 & 13.54 & 14.41 \\
\hline \multicolumn{6}{|l|}{$\begin{array}{l}\text { Primary Heating and Cooling } \\
\text { System }\end{array}$} \\
\hline Heating Source, Efficiency & Heat Pump, 4.25 COP & Gas Furnace, $80 \%$ Et & Gas Furnace, $93 \%$ Et & VRF, 3.48 COPnf & VRF, 4.27 COPnf \\
\hline Boiler Pump Power & NA & NA & NA & NA & NA \\
\hline Cooling Source, Efficiency & DX, 3.57 COP & DX, 4.183 COP & $\mathrm{DX}, 4.74 \mathrm{COP}$ & VRF, 3.33 COPnf & VRF, 4.06COPnf \\
\hline Chiller Pump Control, Pump Power & NA & NA & NA & NA & NA \\
\hline $\begin{array}{l}\text { Cooling Tower Efficiency, } \\
\text { Condenser Pump Power }\end{array}$ & & NA & NA & NA & NA \\
\hline Fan Control, Fan Power (W/CFM) & $\begin{array}{c}\text { On-Off, } \\
0.528 \mathrm{~W} / \mathrm{CFM} \\
\left(1119 \mathrm{~W} \text { per m } \mathrm{m}^{3} / \mathrm{s}\right)\end{array}$ & $\begin{array}{c}\text { On-Off, } \\
0.528 \mathrm{~W} / \mathrm{CFM} \\
\left(1119 \mathrm{~W} \text { per } \mathrm{m}^{3} / \mathrm{s}\right)\end{array}$ & $\begin{array}{l}\text { VAV, } 0.422 \mathrm{~W} / \mathrm{CFM} \\
\left(894 \mathrm{~W} \text { per } \mathrm{m}^{3} / \mathrm{s}\right)\end{array}$ & $\begin{array}{l}\text { CAV, } 0.25 \mathrm{~W} / \mathrm{CFM} \\
\left(530 \mathrm{~W} \text { per } \mathrm{m}^{3} / \mathrm{s}\right)\end{array}$ & $\begin{array}{l}\text { CAV, } 0.25 \mathrm{~W} / \mathrm{CFM} \\
\left(530 \mathrm{~W} \text { per } \mathrm{m}^{3} / \mathrm{s}\right)\end{array}$ \\
\hline Reheat Source & NA & NA & NA & NA & NA \\
\hline Minimum Airflow Fraction & NA & NA & NA & NA & NA \\
\hline Economizer Control & Yes & No & Yes & No & No \\
\hline $\operatorname{ERV}(\mathrm{Y} / \mathrm{N})$ & NA & No & No & No & No \\
\hline ERV Sensible, Latent Effectiveness & NA & NA & NA & NA & NA \\
\hline DCV Control & No & No & No & No & No \\
\hline \multicolumn{6}{|l|}{ DOAS Details } \\
\hline Coupled with DOAS System? & Yes & Yes & Yes & Yes & Yes \\
\hline DOAS Cooling Source, Efficiency & No Cooling & No Cooling & No Cooling & No Cooling & No Cooling \\
\hline DOAS Heating Source, Efficiency & No Heating & No Heating & No Heating & No Heating & No Heating \\
\hline $\begin{array}{c}\text { DOAS Fan Control, Total DOAS } \\
\text { Fan Power }\end{array}$ & $\begin{array}{c}\text { CAV, } \\
0.730 \mathrm{~W} / \mathrm{CFM} \\
\left(1550 \mathrm{~W} \text { per m } \mathrm{m}^{3} / \mathrm{s}\right)\end{array}$ & $\begin{array}{c}\text { CAV, } \\
0.730 \mathrm{~W} / \mathrm{CFM} \\
\left(1550 \mathrm{~W} \text { per m } \mathrm{m}^{3} / \mathrm{s}\right)\end{array}$ & $\begin{array}{c}\text { CAV, } \\
0.620 \mathrm{~W} / \mathrm{CFM} \\
\left(1310 \mathrm{~W} \text { per m } \mathrm{m}^{3} / \mathrm{s}\right)\end{array}$ & $\begin{array}{c}\text { CAV, } \\
0.730 \mathrm{~W} / \mathrm{CFM} \\
\left(1550 \mathrm{~W} \text { per } \mathrm{m}^{3} / \mathrm{s}\right)\end{array}$ & $\begin{array}{c}\text { CAV, } \\
0.730 \mathrm{~W} / \mathrm{CFM} \\
\left(1550 \mathrm{~W} \text { per m } \mathrm{m}^{3} / \mathrm{s}\right)\end{array}$ \\
\hline $\operatorname{ERV}(\mathrm{Y} / \mathrm{N})$ & Yes & Yes & Yes & Yes & Yes \\
\hline ERV SAT Control & Yes & Yes & Yes & Yes & Yes \\
\hline ERV Sensible, Latent Effectiveness & $0.7,0.0$ & $0.6,0.0$ & $0.7,0.0$ & $0.6,0.0$ & $0.6,0.0$ \\
\hline
\end{tabular}

Abbreviations: PSZ-HP: packaged single zone heat pump; VRF: variable refrigerant flow; COPnf: coefficient of performance-no fan.

Large office prototype was analyzed with minimally compliant configurations of four pipe fan coil units with DOAS and ERV with bypass control, VAV with hot water reheat and VAV with electric reheat (Figure 7a,b). WSEC 2018 includes prescriptive requirements for a high efficiency VAV system (Section C403.6.10), which permits the use of multiple-zone VAV systems without a separate parallel DOAS if the system meets specific requirements including, but not limited to, an air-side economizer and 20\% higher chiller efficiency. The minimum VAV with reheat systems also was improved with a higher efficiency boiler, lower fan power and ERV bypass control in order to comply with TSPR requirements.

Similar results for the retail use type are shown below (Figure 8a,b). Minimally prescriptively compliant versions of gas fired single zone furnace and DOAS with variable refrigerant flow systems (VRF) do not comply with WSEC requirements and need to be improved with higher equipment efficiency and in the case of the gas furnace, improved ERV sensible effectiveness to comply. The retail baseline includes an economizer and a higher than minimally required ERV sensible effectiveness which results in a minimal VRF system not complying. The system efficiency is improved to get the system to comply. 


\section{TSPR (Large Office)}

Electricity $0.7 \mathrm{lb} / \mathrm{kWh}$, Gas $11.7 \mathrm{lb} /$ Therm

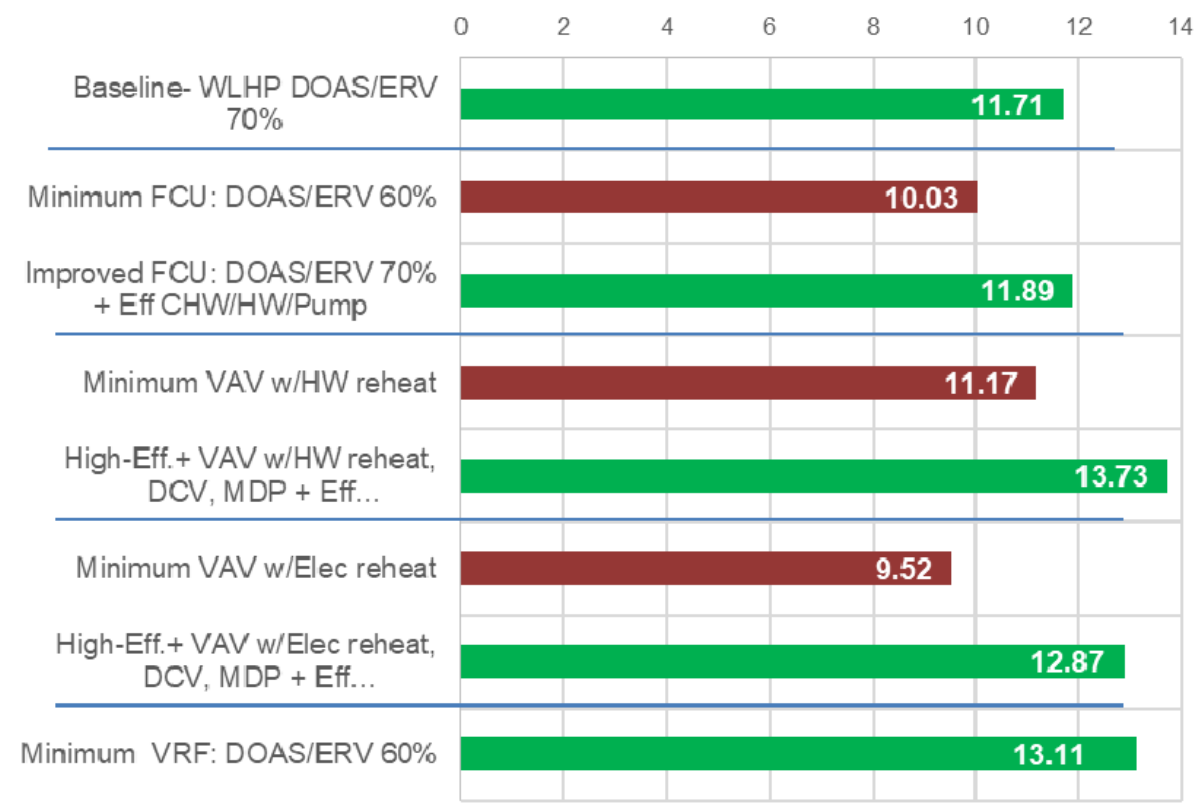

(a)

\section{TSPR (Large Office)}

Electricity $88.2 \mathrm{~kg} / \mathrm{GJ}$, Gas $50.3 \mathrm{~kg} / \mathrm{GJ}$

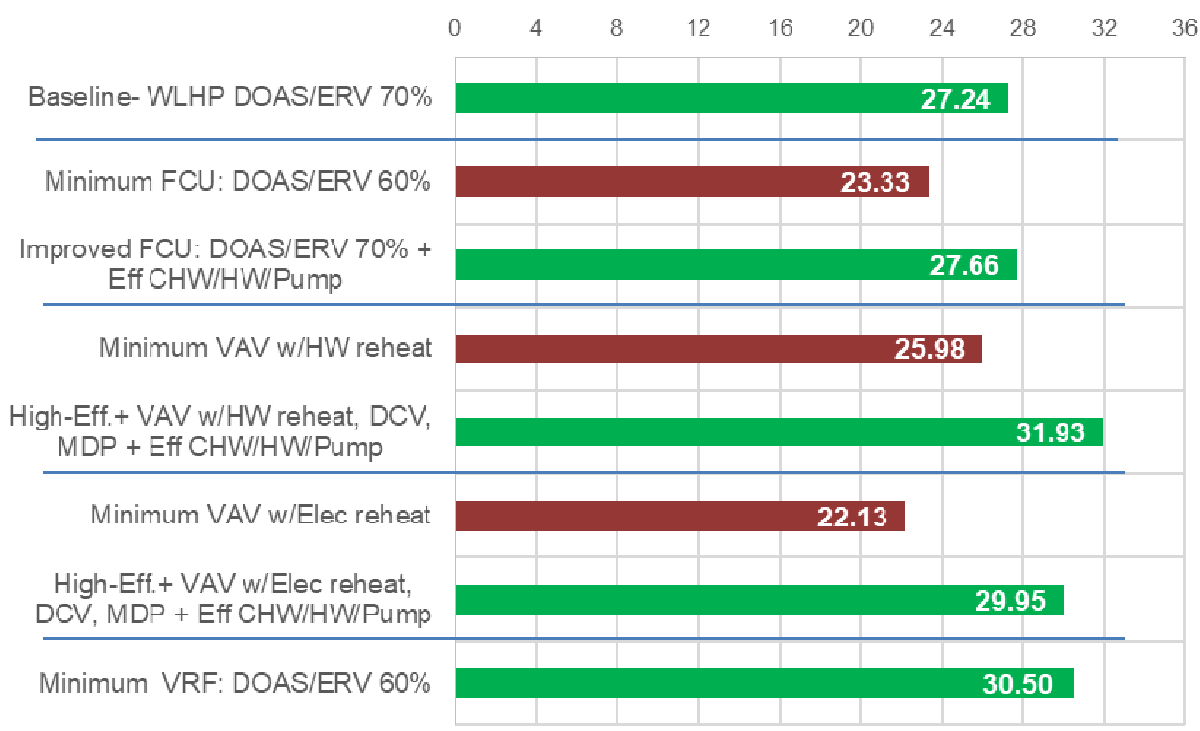

(b)

Figure 7. Results for a large office building analyzed using TSPR tool. (a) IP units; (b) SI units. 
TSPR (Retail)

Electricity $0.7 \mathrm{lb} / \mathrm{kWh}$, Gas $11.7 \mathrm{lb} /$ Therm

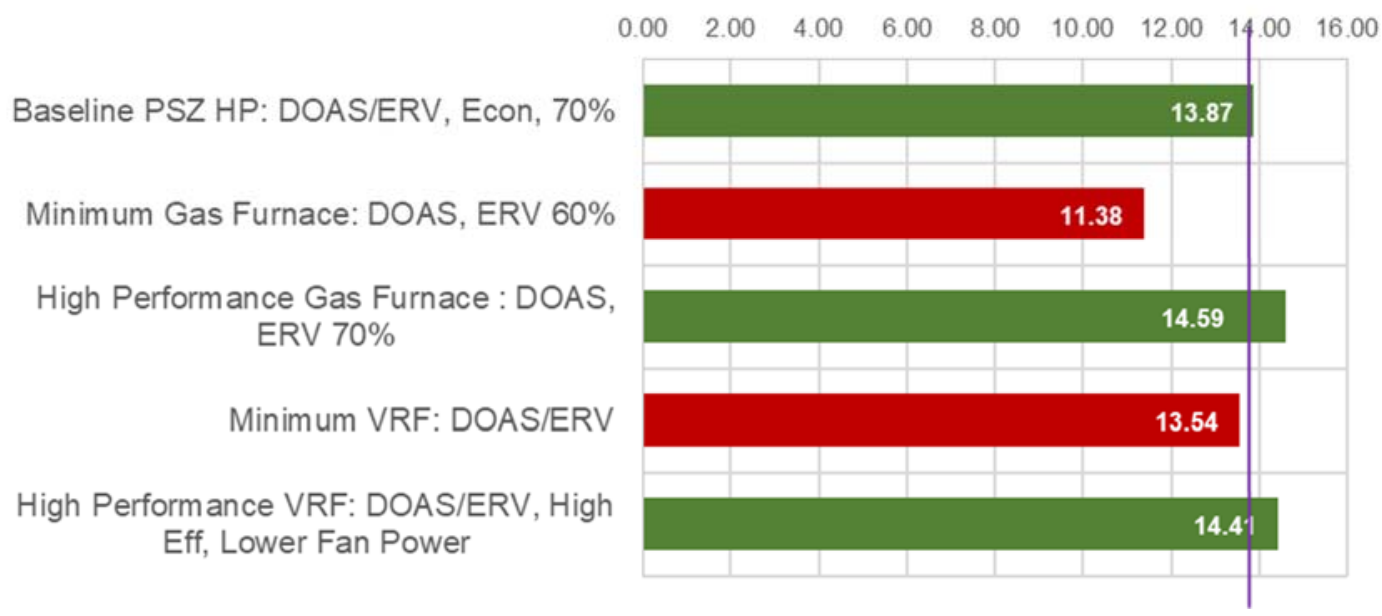

(a)

TSPR (Retail)

Electricity $88.2 \mathrm{~kg} / \mathrm{GJ}$, Gas $50.3 \mathrm{~kg} / \mathrm{GJ}$

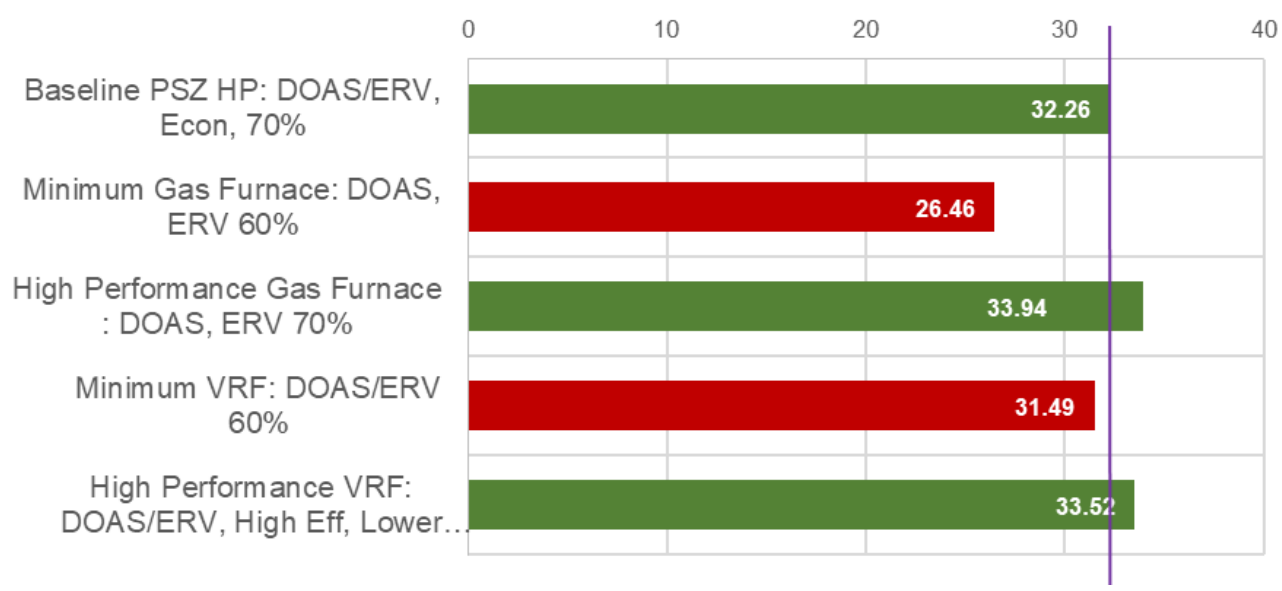

(b)

Figure 8. Results for a retail building analyzed using TSPR tool. (a) IP units; (b) SI units.

\section{Conclusions}

To date, energy codes have relied on either the prescriptive compliance approach or the whole building performance compliance approach to determine code compliance. For the first time, the new HVAC System Performance approach gives the energy code a metric and a minimum standard for evaluating the overall efficiency of a building's HVAC system, without prescribing the technical means of achieving that level of efficiency. This approach can be tailored to meet goals and objectives of the adopting jurisdiction. The stringency of TSPR metric thresholds can be set initially to eliminate only the least efficient systems from consideration and can then be strengthened over future code cycles to require progressively higher-performing systems. This encourages an integrated design approach for the selection and analysis of HVAC systems and can potentially shift the focus of code compliance from that of simply complying with the prescriptive provisions, to that of designing complete integrated systems that interact in a manner that provides the highest levels of efficiency [14]. 
The guidelines and procedures specified in the 2018 version of the WSEC facilitates a standard implementation of this approach to demonstrate compliance with these requirements. The HVAC System Performance tool has implemented these standard procedures and provides a simple web-based tool that can be used to define the proposed building and automatically generate the baseline building and the standard output reports. The standard output reports can be submitted to the code official for review, along with the energy models which are also available through the tool. This reduces the burden associated with verification of performance-based compliance results, allowing for large-scale implementation and broad adoption of the TSPR approach.

While initially developed for a few common building types subject to the WSEC, the HVAC System Performance approach could be applied to any code or building energy standard with customized TSPR calculations. When combined with the whole-building evaluation procedures already available for lighting and for building envelope systems, the HVAC System Performance approach has the potential to move energy codes closer to enacting a building performance standard that is based on hard performance targets, without requiring resource intensive whole building performance path modeling [14].

The HVAC System Performance approach can be applied to any model energy code or beyond code program. Washington State is using carbon emissions as the TSPR evaluation metric, but this could just as well be site energy cost, site energy use or source energy use based on the policy goals of the city, state or jurisdiction applying the HVAC System Performance approach. Baseline systems can also be modified to a configuration appropriate for the climate being analyzed. The authors are currently working with ASHRAE Standing Standard Project Committee 90.1 to explore the use of the HVAC System Performance approach in Standard 90.1. While similar in concept to the WSEC implementation of TSPR, any future adoption by Standard 90.1 would likely include different baseline systems and potentially one or more compliance metrics.

As the HVAC System Performance approach provides a quantitative assessment of the efficiency of the HVAC system compared to a code minimum, it is also a good candidate for utility incentive programs or other programs that reward design in excess of code. Several utility programs in the Northwest are currently exploring adoption of the HVAC System Performance approach.

The HVAC System Performance approach and TSPR metric can redefine the way HVAC systems are evaluated. A similar system performance approach could be developed and implemented for other systems within a building, including envelope and lighting [15]. Aspects of a high-performance system design which, through the prescriptive approach to compliance, were not credited or recognized would become a critical aspect for system evaluation. The simplified implementation of the HVAC System Performance approach through the TSPR tool provides a mechanism for designers and engineers to perform quick analysis to identify how different system design strategies impact the overall performance of the HVAC system. This approach is a critical step towards a systems-based approach for building design and evaluation.

Author Contributions: Conceptualization, M.R.; methodology, M.R. and S.G.; software, J.G. and S.G.; validation, S.G. and J.L.; formal analysis, S.G., J.G. and J.L.; investigation, S.G. and J.L.; data curation, S.G. and J.L.; writing—original draft preparation, S.G. and M.R.; writing—review and editing, M.R., J.G. and J.L.; visualization, S.G. and J.G.; supervision, M.R.; project administration, M.R.; funding acquisition, M.R. All authors have read and agreed to the published version of the manuscript.

Funding: This research was funded by United States Department of Energy, under contract DE-AC0576RL01830, Northwest Energy Efficiency Alliance, City of Seattle, Carbon Neutral Cities Alliance.

Institutional Review Board Statement: Not applicable.

Informed Consent Statement: Not applicable.

Data Availability Statement: Not applicable.

Conflicts of Interest: The authors declare no conflict of interest. 


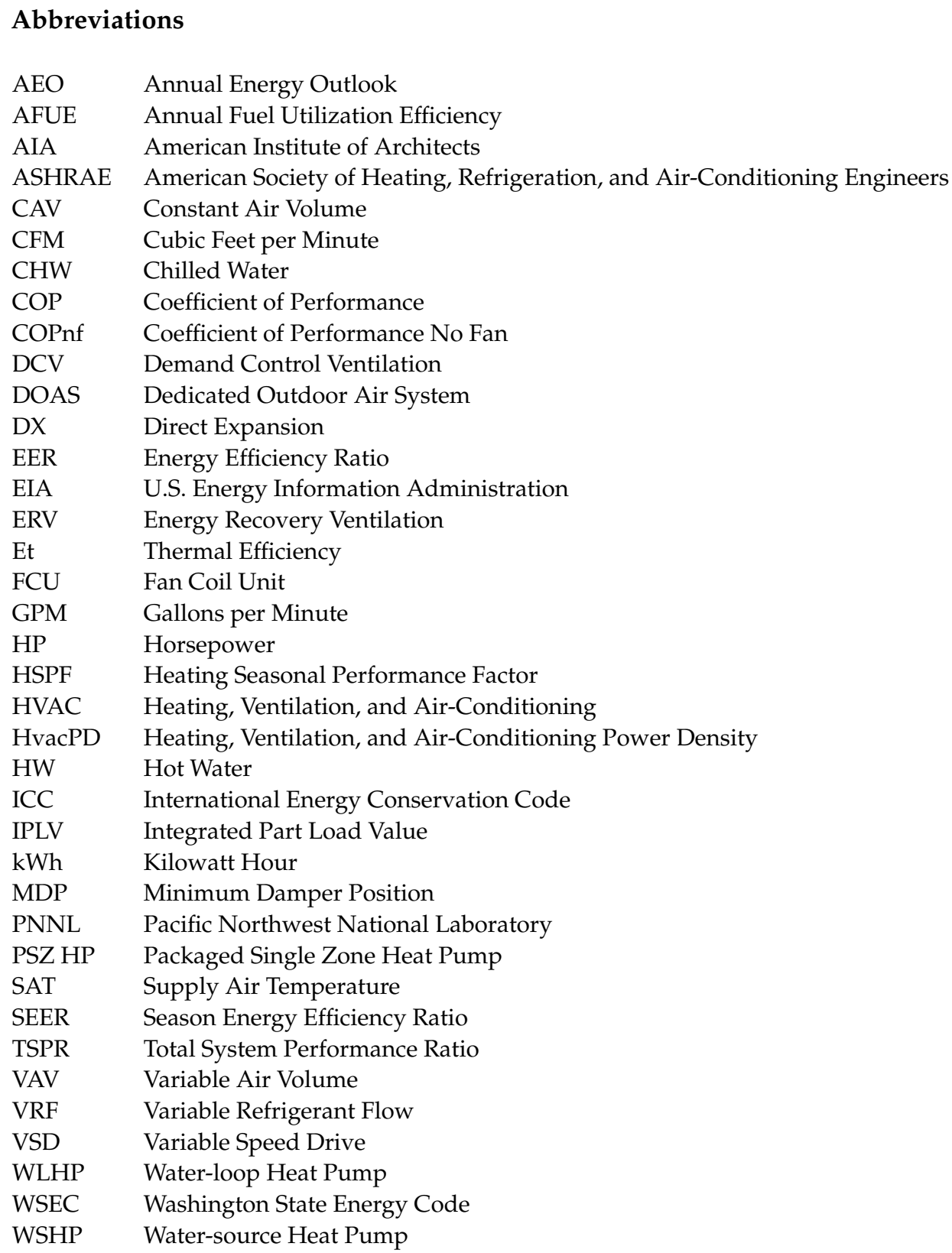

\section{References}

1. ASHRAE (American Society of Heating, Refrigeration and Air-Conditioning Engineers). ASHRAE Standard 90-75, Energy Conservation in New Building Design; American Society of Heating, Refrigerating and Air-Conditioning Engineers: Atlanta, GA, USA, 1975.

2. Jonlin, D.; Thornton, B.; Rosenberg, M.I. Can high performance equipment lead to a low-performing building? In Proceedings of the 2016 ACEEE Summer Study on Energy Efficiency in Buildings, Washington, DC, USA, 21-26 August 2016.

3. ASHRAE. ANSI/ASHRAE/IESNA Standard 90.1-2019-Energy Efficient Design of New Low-Rise Residential Buildings; American Society of Heating, Refrigerating and Air-Conditioning Engineers: Atlanta, GA, USA, 2019.

4. ICC. 2018 International Energy Conservation Code; International Code Council: Washington, DC, USA, 2018.

5. WSEC. Washington State Energy Code, 2018. Washington State Building Code Council, 2018. Available online: https://sbcc.wa. gov/sites/default/ files/2020-04/2018\%20WSEC_C\%202nd\%20print.pdf (accessed on 20 November 2020).

6. AIA (American Institute of Architects). “The 2030 Challenge" 2030 Inc. 2011. Available online: http:/ / www.architecture2030 org/2030_challenge/the_2030_challenge (accessed on 21 March 2021).

7. ASHRAE (American Society of Heating, Refrigerating and Air-Conditioning Engineers). ASHRAE Vision 2020: Providing Tools by 2020 that Enable the Building Community to Produce Market-Viable NZEBs by 2030; American Society of Heating, Refrigerating and Air-Conditioning Engineers: Atlanta, GA, USA, 2008. 
8. Franconi, E.; Lerond, J.; Nambiar, C.; Kim, D.; Winiarski, D.; Rosenberg, M. Filling the Efficiency Gap to Achieve Zero Energy Buildings with Energy Codes (PNNL-30547); Pacific Northwest National Laboratory: Richland, WA, USA, 2021; publication pending.

9. Rosenberg, M.; Hart, R.; Zhang, J.; Athalye, R. Roadmap for the Future of Commercial Energy Codes; Pacific Northwest National Lab.: Richland, WA, USA, 2015.

10. Li, H.; Hong, T.; Lee, S.H.; Sofos, M. System Level Key Performance Indicators for Building Performance Evaluation; Lawrence Berkely National Laboratory: Berkely, CA, USA, 2020. Available online: https:/ / eta-publications.lbl.gov/sites/default/files/systemlevel_key_performance_indicators.pdf. (accessed on 20 June 2021).

11. CGBC 2017. Zero Carbon Building Energy Modeling Guidelines. Canadian Green Building Council, 2017. Available online: https:/ / www.cagbc.org/cagbcdocs/zerocarbon/CaGBC_EMG_for_ZCB_v01.pdf (accessed on 20 June 2021).

12. Rosenberg, M.; Goel, S.; Tillou, M. Paving the way for net zero energy codes through performance based approaches. In Proceedings of the 2020 ACEEE Summer Study on Energy Efficiency in Buildings, Asilomar, CA, USA, 17-21 August 2020.

13. Kavanaugh, S.P.; Lambert, S.; Devin, N. HVAC power density an alternate path to efficiency. ASHRAE J. 2006, $48,40$.

14. Jonlin, D.; Rosenberg, M.I.; Goel, S. TSPR: The Total System Performance Ratio as a metric for HVAC system efficiency. In Proceedings of the 2018 ACEEE Summer Study on Energy Efficiency in Buildings, Asilomar, CA, USA, 12-17 August 2018.

15. Goel, S.; Wang, N.; Rosenberg, M.; Mendon, V. Performance-based building system evaluation for DOE energy asset score. In Proceedings of the ASHRAE Annual Conference, Atlanta, GA, USA, 28 June-2 July 2014.

16. Pérez-Lombard, L.; Ortiz, J.; Maestre, I.R.; Coronel, J.F. Constructing HVAC energy efficiency indicators. Energy Build. 2012, 47, 619-629. [CrossRef]

17. Wang, L. Measuring Whole Building HVAC System Energy Efficiency. Master's Thesis, Texas A\&M University, College Station, TX, USA, 2015. Available online: https:/ / oaktrust.library.tamu.edu/bitstream/handle/1969.1/155683/WANG-THESIS-2015 .pdf?sequence $=1$ (accessed on 20 June 2021).

18. Liao, J.; Claridge, D.E. Analysis of whole-building HVAC system energy efficiency. ASHRAE Trans. $2018,124,72-87$.

19. Kreider, J.F.; Rabl, A. Heating and Cooling of Buildings: Design for Efficiency; McGrawHill: New York, NY, USA, 1994.

20. U.S. Energy Information Administration. Annual Energy Outlook 2020; Energy Information Administration of U.S. Department of Energy: Washington, DC, USA, 2020. Available online: https:/ / www.eia.gov/outlooks/aeo (accessed on 20 June 2021).

21. EnergyPlus. 2018. Available online: https:/ / energyplus.net/ (accessed on 20 March 2018).

22. WSEC. Washington State Energy Code; International Code Council: Country Club Hills, IL, USA, 2015.

23. Lei, X.; Butzbaugh, J.B.; Chen, Y.; Zhang, J.; Rosenberg, M.I. Development of National New Construction Weighting Factors for the Commercial Building Prototype Analyses (2003-2018), PNNL-29787; Pacific Northwest National Laboratory: Richland, WA, USA, 2020. Available online: https:/ / www.osti.gov / servlets / purl/1660807 (accessed on 20 June 2021).

24. DOE. Building Energy Asset Score; U.S. Department of Energy: Washington, DC, USA, 2018. Available online: https://www. energy.gov/eere/buildings/building-energy-asset-score (accessed on 21 March 2018).

25. Wang, N.; Goel, S.; Makhmalbaf, A.; Long, N. Development of building energy asset rating using stock modeling in the USA. J. Build. Perform. Simul. 2016, 11, 4-18. [CrossRef]

26. OpenStudio. 2018. Available online: https: / / openstudio.net (accessed on 20 March 2018).

27. Thornton, B.A.; Sullivan, G.P.; Rosenberg, M.I.; Baechler, M.C. Preserving Envelope Efficiency in Performance Based Code Compliance; Pacific Northwest National Laboratory: Richland, WA, USA, 2015. Available online: http:/ /www.pnnl.gov/main/publications/ external/technical_reports/PNNL-24359.pdf (accessed on 20 June 2021).

28. PNNL. 2021. Available online: https://www.energycodes.gov/development/commercial/prototype_models (accessed on 21 March 2021). 